\title{
Natural bacterioplankton assemblage composition during blooms of Alexandrium spp. (Dinophyceae) in NW Mediterranean coastal waters
}

\author{
Esther Garcés ${ }^{1,2, *}$, Magda Vila ${ }^{1}$, Albert Reñé ${ }^{1}$, Laura Alonso-Sáez ${ }^{1}$, Silvia Anglès ${ }^{1}$, \\ Antonella Lugliè ${ }^{2}$, Mercedes Masó ${ }^{1}$, Josep M. Gasol ${ }^{1}$ \\ ${ }^{1}$ Departament de Biologia Marina i Oceanografia, Institut de Ciències del Mar - CMIMA, CSIC, \\ Pg. Marítim de la Barceloneta, 37-49, 08003 Barcelona, Spain \\ ${ }^{2}$ IRTA, Institut de Recerca i Tecnologia Agroalimentaries, Sant Carles de la Ràpita, Spain \\ ${ }^{3}$ Dipartimento di Botanica ed Ecologia vegetale, University of Sassari, Via Muroni 25, 07100 Sassari, Italy
}

\begin{abstract}
We characterised the spatial and temporal variation in the bacterioplankton assemblage composition during bloom events of different Alexandrium species (Dinophyceae) in the littoral of the NW Mediterranean Sea by means of catalysed reporter deposition fluorescence in situ hybridisation with oligonucleotide probes (CARD-FISH). We studied several Alexandrium blooms through their seasonal development (at La Fosca beach) or in their spatial variability (in Arenys Harbour and Olbia Bay), and we complemented these observations by describing the composition of the bacterial assemblage associated with cultures of Alexandrium species isolated from the same sites. Our studies on natural bacterioplankton assemblages identified the Bacteroidetes lineage and the Alphaproteobacteria as the dominating components during the studied blooms of Alexandrium. Alphaproteobacteria dominated in the La Fosca and Olbia blooms, while bacteria belonging to the Bacteroidetes were abundant in the development phase of the La Fosca beach bloom and in the winter Arenys bloom. Gammaproteobacteria contributed in low proportions without significant changes through the different bloom phases at La Fosca beach and in Olbia Bay, but were more abundant in Arenys Harbour. While the absolute bacterial abundances in the spatial study of Olbia Bay covaried with the Alexandrium densities, there were no spatial changes in the bacterioplankton assemblage composition. Alteromonas-like organisms were never an important fraction of the assemblage, but Roseobacter dominated Alphaproteobacteria in Arenys Harbour. Furthermore, the bacterioplankton assemblages associated with Alexandrium spp. cultures were very different from the natural bacterial assemblages during blooms of the same species. We conclude that the presence of a given harmful algal bloom species during a bloom will not always necessarily be accompanied by the same bacterial assemblage structure, and studies done with dinoflagellate cultures may only reflect the bacteria capable of growing under laboratory conditions, with little resemblance to what occurs under natural conditions.
\end{abstract}

KEY WORDS: FISH · Dinoflagellates $\cdot$ HAB $\cdot$ Alexandrium $\cdot$ Roseobacter $\cdot$ Alteromonas

\section{INTRODUCTION}

Since planktonic algae are the main source of autochthonous production of organic matter, associations between algae and bacteria are thought to be a characteristic feature of the marine environment. These associations may take the form of large-scale correlations between abundance and activities of primary producers and bacteria (e.g. Gasol \& Duarte 2000), or might take more specific forms, such as the reported association between growing diatoms and bacteria belonging to the Flavobacteria family of the Bacteroidetes phylum (Pinhassi et al. 2004, Grossart et al. 2005), or the Bacteroidetes, which have been asso- 
ciated with phytoplankton in some field studies (DeLong et al. 1993, González \& Moran 1997) and mesocosm experiments (Riemann et al. 2000). These associations may be considered as a form of symbiosis or as a form of specific parasitism (Cole 1982).

Driven by the economic and sanitary impacts of harmful algal blooms (HABs), a large research effort is currently underway to understand the ecology of the algal species involved (Granéli \& Turner 2006), as well as the effect of the blooming species on other components of the planktonic food web. Of the many factors said to play a role in HAB dynamics, the interactions between algae and bacteria are increasingly being cited (Kodama et al. 2006). In particular, the presence of specific bacteria has been proposed as an important modulator of the processes of algal bloom initiation, maintenance and decline (Doucette 1995, Adachi et al. 1999, Doucette et al. 1999), but also as a potential modulator of the bloom toxicogenesis (e.g. Gallacher et al. 1997).

If particular bacteria are responsible for certain bloom characteristics, then one might expect to consistently find similar assemblages of bacteria associated with blooming dinoflagellates. Indeed, bacteria from 2 main groups, Alpha- and Gammaproteobacteria, are commonly described as associated with dinoflagellate cultures (Table 1 and references therein) or with natural populations of blooming dinoflagellates (Table 1 and references therein). The literature presents different views about the type of specificity of the association between bacteria and HABs. For example, while some authors have identified the Bacteroidetes as associated with Alexandrium dinoflagellates (Biegala et al. 2002), other studies have convincingly shown that the Roseobacter subgroup of Alphaproteobacteria and the Alteromonas subgroup of Gammaproteobacteria are almost always associated with blooming Alexandrium (Brinkmeyer et al. 2000, Sala et al. 2005). Field studies relating HABs and the composition of the associated bacteria have focused primarily on successional changes and the possible inhibition or stimulation of blooms by the bacteria (Buck \& Pierce 1989, Romalde et al. 1990, Fukami et al. 1991, Onji et al. 1995, Ishida et al. 1997) or their implication in the production and biotransformation of paralytic shellfish toxins (PSTs) (Tobe et al. 2001). This seems to support the underlying idea that there are specific associations between the HAB species and their bacterial assemblages (e.g. Jasti et al. 2005). In any case, the in situ impact of these associations is not clear (Mayali \& Azam 2004), and relatively little is known about how components of natural bacterial assemblages interact with the HAB population.

A clear prediction concerning the composition of the bacterial assemblage accompanying HAB development is not yet possible, in part because most studies describing bacterial assemblage composition in natural dino- flagellate blooms or in cultures of blooming dinoflagellates have relied upon the plate isolation of bacteria (references in Table 1) or upon techniques based on PCR amplification of bacterial rDNA (e.g. Sala et al. 2005). It is well known that the first methodology does not necessarily represent the in situ composition of the bacterial assemblage (e.g. Suzuki et al. 1997), and the techniques based on PCR amplification may suffer from poorly constrained biases (Wintzingerode et al. 1997, Castle \& Kirchman 2004). Methods based on the detection of bacterial 16S rRNA genes with oligonucleotide probes represent a useful tool to gain insight into the composition of bacterioplankton assemblages (Glöckner et al. 1999); these methods are independent of PCR biases. This approach has allowed the detection of highly specific bacterial assemblages on lake snow (Schweitzer et al. 2001) and riverine aggregates (Böckelmann et al. 2000), has been used to study the specificity of associations in some HABs (Doucette et al. 1998), and has also been proven useful for the identification, localisation and quantification of intracellular and associated bacteria in dinoflagellate cultures (Biegala et al. 2002). For our purpose of determining the composition of the bacterial assemblage accompanying the HAB species, a quantitative, cell-based detection method such as fluorescent in situ hybridisation (FISH) seemed most appropriate.

Several recurrent noxious blooms of the genus Alexandrium (A. taylori, A. minutum and A. catenella) provided the opportunity to follow bacterial changes over a wide range of dinoflagellate cell abundances (from $10^{3}$ to $10^{6}$ cells $^{-1}$ ) and different bloom phases (development, maintenance and decline phase), including non-bloom periods. To test the hypothesis that a given dinoflagellate species would have a constant permanently associated bacterial assemblage, the CARD-FISH (catalyzed reporter deposition fluorescence in situ hybridisation; Pernthaler et al. 2002) protocol was used to assess the variation in abundance and composition of the dominant groups of bacterioplankton. We focused on describing the seasonal, spatial and specific variability in bacterial assemblage composition in terms of percent contribution by the major groups, but we also used cultures of the dinoflagellates that we had studied in situ, and an external non-bloom station, to frame our results and to better understand the meaning of the described variability. The specific questions pursued were as follows: (1) What is the composition found in bacterioplankton assemblages during HAB events? (2) Are the bacterial associations specific during blooms of the same dinoflagellate species? (3) Is bacterioplankton assemblage composition affected by high biomass blooms? (4) Are the in situ bacterial associations similar to those of the accompanying bacterial communities during clonal culture growth of the dinoflagellate species? 
Table 1 (continued overleaf). Associations between dinoflagellates and bacteria reported in the literature. Dominant bacterial lineages: those qualitatively dominating the samples (according to authors listed). Bacteroidetes often previously reported as Cytophaga/Flavobacteria/Bacteroidetes; Alteromonas, Pseudoalteromonas, Vibrio, Moraxella and Pseudomonads are Gammaproteobacteria; Roseobacter, Ruegeria and Rhodobacter are Alphaproteobacteria. MPN: most probable number; FISH: fluorescence in situ hybridisation with oligonucleotide probes; DGGE: denaturing gradient gel electrophoresis; TSA: tyramide signal amplification; CARD: catalysed reporter deposition; T-RFLP: terminal restriction fragment length polymorphism; TaqMan qPCR: quantitative PCR with the TaqMan assay

\begin{tabular}{|c|c|c|c|}
\hline $\begin{array}{l}\text { Dinoflagellate } \\
\text { (Site/Samples) }\end{array}$ & Dominant bacterial lineages & Technique & Source \\
\hline \multirow[t]{4}{*}{$\begin{array}{l}\text { Alexandrium affine } \\
\text { (Cultures) }\end{array}$} & $\begin{array}{l}\text { Alphaproteobacteria } \\
\text { (Stappia/Moraxella) }\end{array}$ & FISH & Groben et al. (2000) \\
\hline & Roseobacter, Alteromonas & Plate isolation and FISH & $\begin{array}{l}\text { Gallacher et al. (1997), } \\
\text { Brinkmeyer et al. (2000) }\end{array}$ \\
\hline & Roseobacter, Alteromonas & Plate Isolation & Gallacher et al. (1997) \\
\hline & Roseobacter & $\begin{array}{l}\text { Plate isolation, DGGE, } \\
\text { TRFLP, clone libraries }\end{array}$ & Hold et al. (2001b) \\
\hline \multirow[t]{4}{*}{$\begin{array}{l}\text { A. catenella } \\
\text { (Cultures) }\end{array}$} & $\begin{array}{l}\text { Cytophaga, } \\
\text { Pseudoalteromonas, Ruegeria }\end{array}$ & Plate isolation & Amaro et al. (2005) \\
\hline & Pseudomonas, Moraxella & FISH & Babinchak et al. (1998) \\
\hline & $\begin{array}{l}\text { Gammaproteobacteria > } \\
\text { Bacteroidetes* }^{*}\end{array}$ & Plate isolation & Córdova et al. (2002) \\
\hline & $\begin{array}{l}\text { Roseobacter, } \\
\text { Alphaproteobacteria and } \\
\text { Gammaproteobacteria }\end{array}$ & Plate isolation & Vásquez et al. (2001) \\
\hline $\begin{array}{l}\text { A. catenella } \\
\text { (NW Mediterranean } \\
\text { harbours }^{\mathrm{a}} \text { and Cultures) }\end{array}$ & Roseobacter $>$ Bacteroidetes & DGGE & Sala et al. (2005) \\
\hline \multirow[t]{3}{*}{$\begin{array}{l}\text { A. fundyense } \\
\text { (Cultures) }\end{array}$} & $\begin{array}{l}\text { Alpha-and } \\
\text { Gammaproteobacteria }\end{array}$ & FISH & Babinchak et al. (1998) \\
\hline & Bacteroidetes & TSA-FISH & Biegala et al. (2002) \\
\hline & $\begin{array}{l}\text { Roseobacter }>\text { Bacteroidetes }> \\
\text { Alteromonadaceae }\end{array}$ & DGGE & Jasti et al. (2005) \\
\hline \multirow{3}{*}{$\begin{array}{l}\text { A. fundyense } \\
\text { (Bay of Fundy) }\end{array}$} & Bacteroidetes & DGGE & Ferrier et al. (2002) \\
\hline & & Plate isolation & \\
\hline & Alteromonas & $\begin{array}{l}\text { DGGE } \\
\text { Plate isolation }\end{array}$ & Ferrier et al. (2002) \\
\hline \multirow{2}{*}{$\begin{array}{l}\text { A. minutum (including } \\
\text { when reported as }\end{array}$} & Pseudomonas & FISH & Babinchak et al. (1998) \\
\hline & Roseobacter, Alteromonas & Plate isolation, FISH & Brinkmeyer et al. (2000) \\
\hline \multirow{7}{*}{$\begin{array}{l}\text { A. lusitanicum) } \\
\text { (Cultures) }\end{array}$} & Pseudomonas stutzeri & Plate isolation & Franca et al. (1995) \\
\hline & Roseobacter and Alteromonas & Plate isolation & Gallacher et al. (1997) \\
\hline & $\begin{array}{l}\text { Alpha- and } \\
\text { Gammanroteobacteria }\end{array}$ & $\begin{array}{l}\text { Plate isolation, DGGE, } \\
\text { TRFLP }\end{array}$ & Hold et al. (2001a) \\
\hline & GammIIPIoteondcteild & Clone libraries & \\
\hline & Pseudomonas & Plate isolation & Franca et al. (1996) \\
\hline & Gamma- and & Plate isolation & Lu et al. (2000) \\
\hline & $\begin{array}{l}\text { Alphaproteobacteria } \\
\text { (intracellular) and Gamma-, } \\
\text { Alphaproteobacteria } \\
\text { Bacteriodetes (extracellular) }\end{array}$ & & \\
\hline $\begin{array}{l}\text { A. minutum } \\
\text { (NW Mediterranean } \\
\text { harbours }^{\mathrm{a}} \text { and Cultures) }\end{array}$ & Roseobacter $>$ Bacteroidetes & DGGE & Sala et al. (2005) \\
\hline $\begin{array}{l}\text { Alexandrium spp. } \\
\text { (Orkney Islands) }\end{array}$ & Roseobacter, Alteromonas & $\begin{array}{l}\text { FISH (several } \\
\text { Alteromonas and } \\
\text { Roseobacter probes) }\end{array}$ & Tobe et al. (2001) \\
\hline $\begin{array}{l}\text { Alexandrium spp. Non- } \\
\text { Toxic and Toxic } \\
\text { (Cultures) }\end{array}$ & $\begin{array}{l}\text { Alphaproteobacteria } \\
\text { and Gammaproteobacteria }\end{array}$ & FISH & Babinchak et al. (1998) \\
\hline \multirow{3}{*}{$\begin{array}{l}\text { A. tamarense } \\
\text { (Cultures) }\end{array}$} & Pseudomonas & FISH & Babinchak et al. (1998) \\
\hline & Bacteroidetes, Alteromonas & TSA-FISH & Biegala et al. (2002) \\
\hline & Roseobacter, Alteromonas & $\begin{array}{l}\text { Plate isolation } \\
\text { FISH }\end{array}$ & Brinkmeyer et al. (2000) \\
\hline
\end{tabular}


Table 1 (continued)

\begin{tabular}{|c|c|c|c|}
\hline $\begin{array}{l}\text { Dinoflagellate } \\
\text { (Site/Samples) }\end{array}$ & Dominant bacterial lineages & Technique & Source \\
\hline & Alteromonas & Plate isolation & Doucette \& Trick (1995) \\
\hline & $\begin{array}{l}\text { Roseobacter and Alteromonas } \\
\text { Alphaproteobacteria }\end{array}$ & Plate isolation & Gallacher et al. (1997) \\
\hline & and Gammaproteobacteria & $\begin{array}{l}\text { Plate isolation, DGGE, } \\
\text { TRFLP } \\
\text { Clone libraries }\end{array}$ & Hold et al. (2001a) \\
\hline & $\begin{array}{l}\text { Roseobacter }>\text { Bacteroidetes }> \\
\text { Alteromonadaceae }\end{array}$ & DGGE & Jasti et al. (2005) \\
\hline & Moraxella & Plate isolation & Kodama et al. (1990) \\
\hline & Gammaproteobacteria & $\begin{array}{l}\text { Plate isolation } \\
\text { Dot-blot hybridization } \\
\text { with probes }\end{array}$ & Kopp et al. (1997) \\
\hline & $\begin{array}{l}\text { Alphaproteobacteria } \\
\text { (Stappia/Moraxella) }\end{array}$ & Plate isolation & Groben et al. (2000) \\
\hline \multirow{2}{*}{$\begin{array}{l}\text { A. tamarense } \\
\text { (Hiroshima Bay, Japan) }\end{array}$} & Alteromonas and Vibrio & $\begin{array}{l}\text { MPN bioassay for } \\
\text { inhibitory bacteria }\end{array}$ & Adachi et al. (2001) \\
\hline & $\begin{array}{l}\text { Roseobacter, Rhodobacter } \\
\text { and Pseudomonads }\end{array}$ & Plate isolation & Adachi et al. (2003) \\
\hline $\begin{array}{l}\text { A. tamarense } \\
\text { (Orkney Islands } \\
\text { and Firth of Forth) }\end{array}$ & $\begin{array}{l}\text { Roseobacter, Bacteroidetes } \\
\text { and Alteromonadaceae }\end{array}$ & $\begin{array}{l}\text { DGGE } \\
\text { Plate isolation }\end{array}$ & Wichels et al. (2004) \\
\hline \multirow{2}{*}{$\begin{array}{l}\text { Gambierdiscus toxicus } \\
\text { (Cultures) }\end{array}$} & Alteromonas sp. & Plate isolation & Sakami et al. (1999) \\
\hline & $\begin{array}{l}\text { Gammaproteobacteria > } \\
\text { Bacteroidetes > Actinobacteria }\end{array}$ & Plate isolation & Tosteson et al. (1989) \\
\hline $\begin{array}{l}\text { Gymnodinium catenatum } \\
\text { (Cultures) }\end{array}$ & $\begin{array}{l}\text { Pseudomonas } \\
\text { Alphaproteobacteria } \\
\text { (Rhodobacteraceae) and } \\
\text { Gammaproteobacteria } \\
\text { (Alteromonadaceae) }\end{array}$ & $\begin{array}{l}\text { Plate isolation } \\
\text { Plate isolation }\end{array}$ & $\begin{array}{l}\text { Franca et al. (1996) } \\
\text { Green et al. (2004) }\end{array}$ \\
\hline $\begin{array}{l}\text { Gymnodinium catenatum } \\
\text { (Rías in Galicia) }\end{array}$ & $\begin{array}{l}\text { Vibrio, Pseudomonas, } \\
\text { Moraxella and other } \\
\text { Gammaproteobacteria }\end{array}$ & Plate isolation & Romalde et al. (1990) \\
\hline $\begin{array}{l}\text { Gyrodinium instriatum } \\
\text { (Cultures) }\end{array}$ & $\begin{array}{l}\text { Bacteroidetes (intracellular) } \\
\text { and Gammaproteobacteria } \\
\text { (extracellular) }\end{array}$ & FISH & Alverca et al. (2002) \\
\hline $\begin{array}{l}\text { Karenia brevis (= } \\
\text { Ptychodiscus brevis) } \\
\text { (Blooms in Florida } \\
\text { Gulf coast) }\end{array}$ & Gammaproteobacteria & Plate isolation & Buck \& Pierce (1989) \\
\hline $\begin{array}{l}\text { K. mikimotoi } \\
\text { (=Gymnodinium mikimotoi) } \\
\text { (Cultures) }\end{array}$ & $\begin{array}{l}\text { Gammaproteobacteria } \\
\text { Moraxella, vibrio }\end{array}$ & $\begin{array}{l}\text { Plate isolation } \\
\text { Plate isolation }\end{array}$ & $\begin{array}{l}\text { Ishida et al. (1997) } \\
\text { Onji et al. (1995) }\end{array}$ \\
\hline $\begin{array}{l}\text { Lingulodinium polyedrum } \\
\text { (Scripps Pier) }\end{array}$ & $\begin{array}{l}\text { Bacteroidetes } \\
\text { Bacteroidetes }\end{array}$ & $\begin{array}{l}\text { DGGE } \\
\text { TaqMan qPCR }\end{array}$ & $\begin{array}{l}\text { Fandino et al. (2001) } \\
\text { Fandino et al. (2005) }\end{array}$ \\
\hline $\begin{array}{l}\text { Ostreopsis lenticularis } \\
\text { (Cultures) }\end{array}$ & $\begin{array}{l}\text { Gammaproteobacteria > } \\
\text { Bacteroidetes > Actinobacteria }\end{array}$ & Plate isolation & Tosteson et al. (1989) \\
\hline Pfisteria sp. (Cultures) & $\begin{array}{l}\text { Alphaproteobacteria } \\
\text { (Rugiera algicola) }\end{array}$ & $\begin{array}{l}\text { Plate isolation } \\
\text { Clon libraries }\end{array}$ & Alavi et al. (2001) \\
\hline $\begin{array}{l}\text { Prorocentrum lima } \\
\text { (Cultures) }\end{array}$ & Roseobacter & Plate isolation & $\begin{array}{l}\text { Lafay et al. (1995), } \\
\text { Prokic et al. (1998) }\end{array}$ \\
\hline $\begin{array}{l}\text { Prorocentrum minimum } \\
\text { (Cultures) }\end{array}$ & $\begin{array}{l}\text { Roseobacter > Bacteroidetes }> \\
\text { Alteromonadaceae }\end{array}$ & DGGE & Jasti et al. (2005) \\
\hline $\begin{array}{l}\text { Scrippsiella sp. } \\
\text { (Cultures) }\end{array}$ & $\begin{array}{l}\text { Roseobacter > Bacteroidetes }> \\
\text { Alteromonadaceae }\end{array}$ & DGGE & Jasti et al. (2005) \\
\hline $\begin{array}{l}\text { Scrippsiella trochoidea } \\
\text { (Cultures) }\end{array}$ & Bacteroidetes & $\begin{array}{l}\text { Plate Isolation, DGGE, } \\
\text { TRFLP } \\
\text { Clone libraries }\end{array}$ & Hold et al. (2001b) \\
\hline
\end{tabular}




\section{MATERIALS AND METHODS}

Surface samples were regularly collected during the development of 3 different dinoflagellate blooms in coastal waters of the NW Mediterranean (Fig. 1). The blooms were dominated by the target species Alexandrium taylori Balech (at La Fosca beach) and A. minutum Halim (Arenys Harbour) along the Catalan coast (NE Spain), and several Alexandrium species, mainly A. catenella (Whedon et Kofoid) Balech, A. tamarense (Lebour) Balech and A. minutum in Olbia Bay (NE Sardinia) in the Tyrrhenian Sea (Italy). All these sites are confined areas where dinoflagellate blooms regularly occur, developing at a very wide range of density and biomass values. These results were compared with those from a site not affected by Alexandrium blooms: the Microbial Observatory of Blanes Bay (MOBB), also on the NW Mediterranean Catalan coast, but in an open bay (Vaqué et al. 1997, Duarte et al. 1999, Alonso-Sáez et al. 2007).

Seasonal sampling was performed at La Fosca beach, located on the Costa Brava (NW Mediterranean Sea, $41^{\circ} 51^{\prime} \mathrm{N}, 3^{\circ} 8^{\prime} \mathrm{E}$; Fig. 1A). This is a semi-enclosed bay $(525 \times 300 \mathrm{~m})$ that opens towards the SE. Detailed information on Alexandrium taylori blooms at this location has been previously published (Garcés et al. 1998, 1999, 2002, 2005). Spatial studies were carried out in Arenys Harbour and Olbia Bay (Fig. 1B,C). Arenys Harbour is located on the NE Spanish coast (NW Mediterranean Sea, $41^{\circ} 34^{\prime} \mathrm{N}$, $2^{\circ} 33^{\prime} \mathrm{E}$ ). Depth ranges from 1 to $2.5 \mathrm{~m}$ at the dockside to maxima of 5 to $6 \mathrm{~m}$ in the central area and at the harbour entrance. The harbour is characterised by strong variations in salinity related to the inflow of terrestrial freshwater. Detailed information on A. minutum blooms at this location has been previously published (Vila et al. 2001, 2005). The Olbia Bay $\left(40^{\circ} 55^{\prime} \mathrm{N}, 9^{\circ} 30^{\prime} \mathrm{E}\right)$ is located in the inner part of the Gulf of Olbia. It is a typical estuary with long water renewal time and significant freshwater inflow from 2 municipal sewers and the Padrongianus River. The Olbia Bay hosts one of the most important commercial ports (with urban, tourism and industrial activities), and is the largest shellfish farming (mussels and clams) area of Sardinia. The bay has an area of $6.5 \mathrm{~km}^{2}$, is about $7 \mathrm{~km}$ long and between 1 and $3 \mathrm{~km}$ wide, it has a mean depth of about $5 \mathrm{~m}$ and a maximum depth of about $10 \mathrm{~m}$, along the central channel. Detailed information on blooms at this location has been previously published (Sannio et al. 1997, Lugliè et al. 2003a,b, 2005).

Field sampling. Between June and September 2003 surface sampling from the shore of La Fosca beach (maximum depth, 1 m; Fig. 1) was conducted once a week. Spatial variation of the bacterioplankton assemblage in Arenys Harbour was intensively monitored during the 2002 bloom. Samples were collected at different locations ( 6 stations) across the harbour, during the maintenance phase of the dinoflagellate bloom (18 February 2002), just after the maximum cell concentration was reached (see Vila et al. 2005 for details).

In Olbia Bay, spatial variation of the bacterioplankton assemblage was monitored on 11 May 2003, just after a PST-positive period (>800 $\mu \mathrm{g} \mathrm{kg}^{-1}$ saxitoxin) that was associated with the presence of Alexandrium.
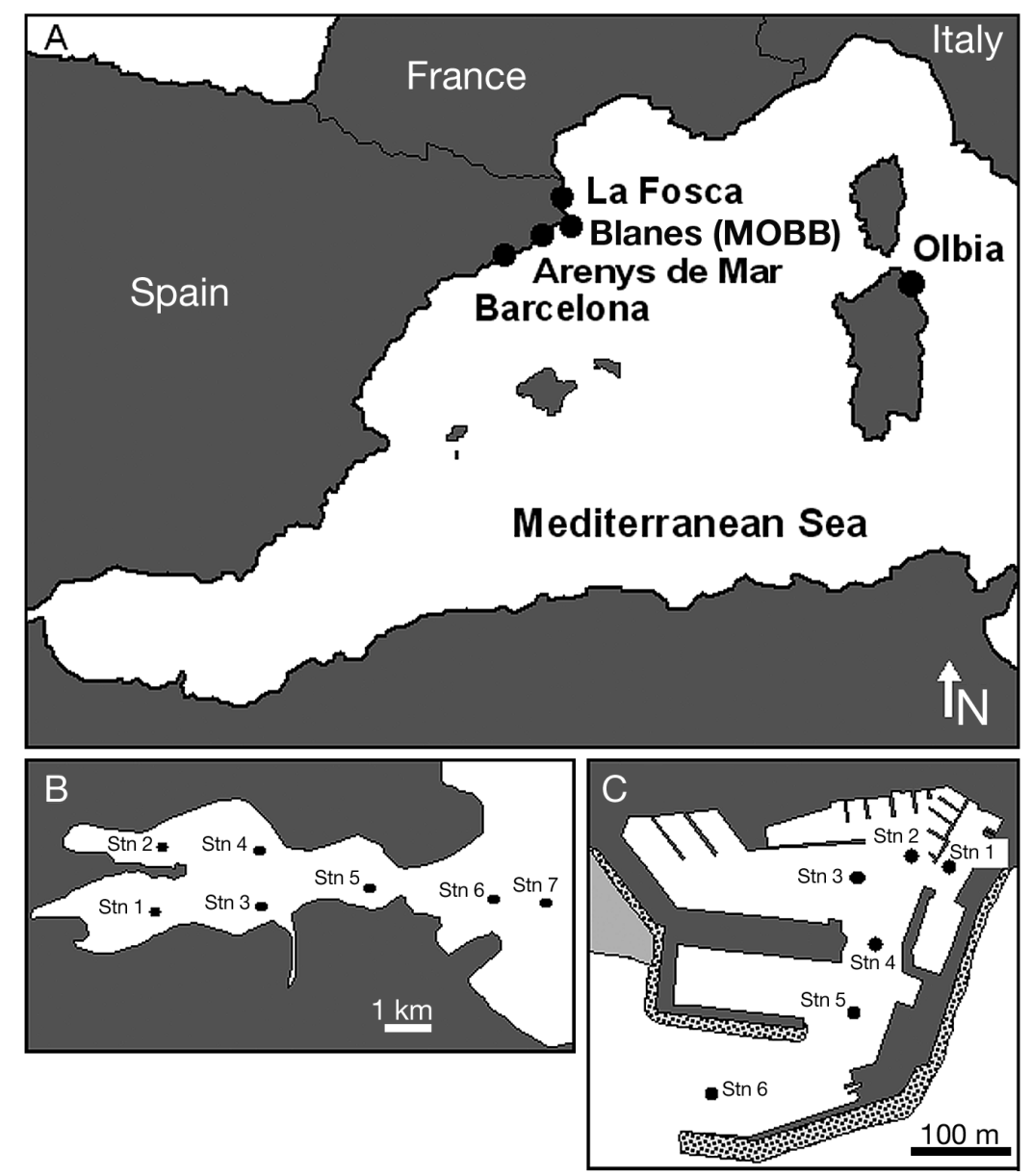

Fig. 1. (A) Geographic location of the stations in the western Mediterranean: La Fosca beach, Arenys Harbour and Blanes Bay (Catalonia, Spain), and Olbia Bay (Sardinia, Italy). Fixed stations were sampled at La Fosca beach (from the shore) and at the Microbial Observatory of Blanes Bay (MOBB). Stations sampled in (B) Olbia Bay and (C) Arenys de Mar Harbour are shown 
Surface samples were collected from 7 stations across the bay, during the end phase of the toxic event. Samples were collected in 51 bottles and immediately transported to the laboratory for appropriate fixation procedures within $1 \mathrm{~h}$. In the case of Arenys, the samples were fixed in situ. In the case of La Fosca and Arenys, subsamples $(50 \mathrm{ml})$ for nutrient measurements were frozen upon arrival in the laboratory and concentrations of nitrate, nitrite, ammonia, phosphate and silicate were determined with an autoanalyser following Grasshoff et al. (1983). Olbia samples for nutrients were frozen and then analysed according to Strickland \& Parsons (1972).

Subsamples $(60 \mathrm{ml})$ for the quantification of total chlorophyll a ( $\mathrm{chl}$ a) were filtered onto $25 \mathrm{~mm}$ Whatman $\mathrm{GF} / \mathrm{F}$ glass fibre filters. Filters were extracted in $8 \mathrm{ml}$ of $90 \%$ acetone, and concentrations of chl a were measured with a Turner Designs fluorometer following Yentsch \& Menzel (1963). At the Olbia stations, chl a was estimated in situ using a calibrated multiparametric probe (Idromar). The same instrument was used to record temperature and salinity values (data not shown).

Duplicate subsamples $(60 \mathrm{ml})$ for measurements of DOC (dissolved organic carbon) in the La Fosca samples were filtered through precombusted glass fibre filters (25 mm Whatman GF/F). Filtrates were collected in precombusted glass ampoules, acidified and stored at $4^{\circ} \mathrm{C}$ until analysed in a Shimadzu 5000 ASI TOC instrument following Sugimura \& Suzuki (1998).

Phytoplankton identification and quantification. The phytoplankton samples $(150 \mathrm{ml})$ were preserved with Lugol iodine solution, except those from Olbia (500 ml), which were fixed with $4 \%$ neutralised formaldehyde. The general procedure for identifying and quantifying phytoplankton cells from La Fosca and Arenys Harbour involved sedimentation ( $24 \mathrm{~h}$ ) of a subsample in a $50 \mathrm{ml}$ settling chamber and subsequent counting of cells in an appropriate area (Throndsen 1995) using a Leica-Leitz DM-IL inverted microscope. Olbia phytoplankton densities were enumerated allowing the original $500 \mathrm{ml}$ samples to settle for $3 \mathrm{~d}$, removing the upper $450 \mathrm{ml}$, collecting the residual $50 \mathrm{ml}$, of which $10 \mathrm{ml}$ was allowed to settle for $8 \mathrm{~h}$. Cells were counted in the entire chamber using a Zeiss Axiovert 100 inverted microscope. Fixed specimens of Alexandrium species were stained with Calcofluor White M2R (Fritz \& Triemer 1985) and examined in an epifluorescence microscope under ultraviolet excitation (Axioplan, filter set Zeiss 487902, 1000× magnification). Tabular formula and morphological features of the thecal plates were studied following the criteria of Balech (1995).

Algal cultures and associated bacterioplankton. Clonal strains of Alexandrium taylori (CSIC-AV8 isolated from La Fosca beach in 1998, EMBL Accession No. AJ251654), A. minutum (CSIC-1 isolated from
Arenys Harbour in 1995, EMBL Accession No. AJ312945) and A. catenella (CSIC-4 isolated from Barcelona Harbour in 1998, EMBL Accession No. AJ298900) were used to study the associated bacterial assemblages. Cultures were established from vegetative cells in $f / 2$ media (Guillard 1975) and maintained at $20^{\circ} \mathrm{C}$ in a $12 \mathrm{~h}$ light: $12 \mathrm{~h}$ dark photocycle. Illumination was provided at a photon irradiance of $100 \mu \mathrm{mol}$ $\mathrm{m}^{-2} \mathrm{~s}^{-1}$. Samples $(60 \mathrm{ml})$ of culture in different growth phases (exponential, maintenance) and a 1 yr-old culture (for A. taylori only) were fixed in Lugol's iodine for phytoplankton counts and processed for bacterial analyses.

Bacterial analyses. To study the associated bacterial assemblage, 10 to $50 \mathrm{ml}$ was filtered onto $0.2 \mu \mathrm{m}$ pore size Nuclepore filters (25 $\mathrm{mm}$ diameter) with a gentle vacuum of 150 mbar at room temperature. Bacteria were fixed by addition of $1 \%$ formaldehydephosphate-buffered saline (PBS) (at pH 7.2). Cellulose nitrate support filters were employed to favour homogeneous distribution of cells. The fixative was eliminated $30 \mathrm{~min}$ later, and filters were rinsed with $2 \mathrm{ml}$ PBS and Milli-Q water. The samples were subsequently stored at $-80^{\circ} \mathrm{C}$ until further processing (within a few months). Total numbers of bacteria were determined by epifluorescence microscopy of 4'6'-diamidino-2-phelylindole (DAPI)-stained samples. DAPI-stainable and probe-specific bacteria were counted in a minimum of 10 randomly selected view fields, at $1000 \times$ magnification, until 300 to 500 cells were counted. In these samples the coefficient of variation of the DAPI counts was $16 \%$ (mean). The composition of the bacterial assemblage was determined by in situ hybridisation with horse-radish peroxidase (HRP)-labelled probes (Pernthaler et al. 2002) listed in Table 2. Filters were dipped in low-gelling-point agarose $(0.1 \%[\mathrm{w} / \mathrm{v}])$, dried upside down at $37^{\circ} \mathrm{C}$ and subsequently dehydrated in $96 \%(\mathrm{v} / \mathrm{v})$ analytical grade ethanol. For cell wall permeabilisation, filters were incubated in a lysozyme solution $\left(10 \mathrm{mg} \mathrm{ml}^{-1}\right.$,

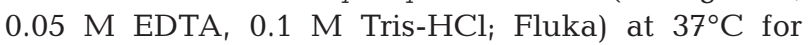
$60 \mathrm{~min}$, followed by a digestion by achromopeptidase $\left(60 \mathrm{U} \mathrm{ml}^{-1}\right)$ for $30 \mathrm{~min}$. The achromopeptidase incubations were performed at $37^{\circ} \mathrm{C}$ in a buffer containing $0.01 \mathrm{M} \mathrm{NaCl}$ and $0.01 \mathrm{M}$ Tris- $\mathrm{HCl}(\mathrm{pH}$ 8). The filters were washed with Milli-Q water, dehydrated with $96 \%$ ethanol, dried at room temperature and subsequently stored on Petri dishes at $-20^{\circ} \mathrm{C}$ until further processing. Filters were cut in sections for hybridisation with oligonucleotide probes. A volume of $3 \mu \mathrm{l}$ of the HRP probe working solution $\left(50 \mathrm{ng} \mathrm{\mu l}^{-1}\right)$ was added to $900 \mu$ l hybridisation buffer $(0.9 \mathrm{M} \mathrm{NaCl}$, $20 \mathrm{mM}$ Tris $-\mathrm{HCl}, 10 \%$ dextran sulphate $[\mathrm{w} / \mathrm{v}], 0.02 \%$ sodium dodecyl sulphate [SDS] and $1 \%$ blocking reagent) containing $45 \%$ formamide $(\mathrm{v} / \mathrm{v})$ for the 
ALF968 probe, $20 \%$ formamide for the NON338 probe and $55 \%$ formamide for the other probes. Probe GAM42a was used with a BETA42a competitor oligonucleotide (Manz et al. 1992). Hybridisation of filter sections was performed at $35^{\circ} \mathrm{C}$ for $2 \mathrm{~h}$. Thereafter, the sections were transferred to $50 \mathrm{ml}$ of pre-warmed washing buffer (5 mM EDTA [pH 8], $20 \mathrm{mM}$ Tris-HCl [pH 7.6], $0.01 \%$ [w/v] SDS) containing $16 \mathrm{mM} \mathrm{NaCl}$ for ALF968, $135 \mathrm{mM}$ for NON338 and $3 \mathrm{mM}$ for the other probes employed. Washing was performed for $5 \mathrm{~min}$ at $37^{\circ} \mathrm{C}$. Sections were then placed in PBS solution at room temperature for $15 \mathrm{~min}$. After removal of excess buffer, the filter sections were immediately transferred to $1.5 \mathrm{ml}$ reaction vials containing $1 \mathrm{ml}$ amplification buffer (1× PBS [pH 7.6], $10 \%$ [w/v] dextran sulphate, $2 \mathrm{M} \mathrm{NaCl}, 0.1 \%$ [w/v] blocking reagent and $0.0015 \%$ $\mathrm{H}_{2} \mathrm{O}_{2}$ in PBS) and $4 \mu \mathrm{l}$ of tyramide-Alexa488 (1 mg $\mathrm{ml}^{-1}$ ) and incubated in the dark at $46^{\circ} \mathrm{C}(15 \mathrm{~min})$. The $\mathrm{H}_{2} \mathrm{O}_{2}$ solution was freshly prepared before being employed. P-iodophenylboronic acid $\left(20 \mathrm{mg} \mathrm{mg}^{-1}\right.$ tyramide) was added to the tyramide-Alexa488 probe to enhance the CARD-FISH signal. After amplification, filters were washed in PBS (room temperature, 15 min), Milli-Q water and 96\% ethanol, and subsequently air dried. Finally, filter sections were mounted in a mixture that contained 4 parts Citifluor (Citifluor) and 1 part Vecta Shield (Vector Laboratories) containing DAPI (final concentration: $1 \mu \mathrm{g} \mathrm{ml} \mathrm{m}^{-1}$ ). The hybridised samples were visualised with a Nikon epifluorescence microscope equipped with a $100 \mathrm{~W} \mathrm{Hg}$ lamp and the appropriate filter sets for DAPI and Alexa488; >300 to 500 DAPI-stained cells were counted per sample.

Statistical analyses. To identify potentially important variables controlling the temporal and spatial dynamics of phytoplankton and bacterial abundance, a correlation analysis was performed with the STATISTICA (StatSoft) software package. Biological data employed were log-transformed prior to analysis to fit a lognormal distribution, and the probabilities reported are Bonferroni corrected.

\section{RESULTS}

\section{Temporal variation: the Alexandrium taylori bloom at La Fosca beach}

During the 4 mo of sampling (June to September), Alexandrium taylori densities increased from $10^{4}$ to $10^{6}$ cells $1^{-1}$ during the development phase from June to July. The maintenance phase occurred in July. The decline phase of the bloom was marked by a sharp decrease in cell numbers detected during August (Fig. 2A). Concentrations of chl a varied between 0.5 and $41 \mu \mathrm{g} \mathrm{l}^{-1}$ during the bloom (Fig. 2B), with a chl a maximum that coincided with maximum DOC concentrations (Fig. 2C). High values of DOC (>200 $\mu \mathrm{M})$ were also measured during the decline phase of the bloom. Dissolved inorganic nitrogen (DIN) ranged between 0.5 and $3 \mu \mathrm{M} \mathrm{N}$ during the bloom (Fig. $2 \mathrm{C}$ ) and $\mathrm{P}^{-\mathrm{PO}_{4}}$ between 0.1 and $4.6 \mu \mathrm{M}$ (details not shown).

Unfortunately, the bacterioplankton samples for July were lost, and the remaining samples for analyses of the bacterioplankton assemblage covered 2 of the bloom phases (development and decline), as well as a non-bloom situation (Fig. 2). Detection of bacteria by Probe EUB338 ranged from 70 to $90 \%$ of the total DAPI-stainable cells present. Bacteria scoring positive with the negative control probe were $<1 \%$ of the DAPI count. The bacterial assemblage changed during the different bloom stages. Bacteroidetes and Alphaproteobacteria dominated in the early stage of the development phase, with maximum densities of $10^{6}$ cells $\mathrm{ml}^{-1}$, and showed a decreasing tendency during the following weeks (down to $10^{5}$ cells ml $^{-1}$; Fig. 2A). The 2 groups were dominant again in the decline phase. Alphaproteobacteria always remained $>10^{5}$ cells ml $^{-1}$, and the Bacteroidetes showed a decline from $10^{5}$ to $10^{4}$ cells $\mathrm{ml}^{-1}$. Gammaproteobacteria densities were always lower than those of the Bacteroidetes and Alphaproteobacteria; they ranged from a maximum of $10^{5}$ cells $\mathrm{ml}^{-1}$ at the beginning of the development phase to a minimum of $8 \times 10^{3}$ cells $\mathrm{ml}^{-1}$ in the non-

Table 2. Sequences, target groups, and origin of the probes used in this study

\begin{tabular}{|llll|}
\hline \multicolumn{1}{|c}{ Target group } & \multicolumn{1}{c|}{ Sequence (5'-3') } & Source \\
\hline EUB338 & Bacteria & GCT GCC TCC CGT AGG AGT & Amann et al. (1990) \\
EUB338 II & Bacteria & GCA GCC ACC CGT AGG TGT & Daims et al. (1999) \\
EUB338 III & Bacteria & GCT GCC ACC CGT AGG TGT & Daims et al. (1999) \\
NON338 & Negative control & ACT CCT ACG GGA GGC AGC & Manz et al. (1992) \\
ALFA968 & Alpha subclass of Proteobacteria & GGT AAG GTT CTG CGC GTT & Glöckner et al. (1999) \\
BET42a & Beta subclass of Proteobacteria & GCC TTC CCA CTT CGT TT & Manz et al. (1992) \\
GAM42a & Gamma subclass of Proteobacteria & GCC TTC CCA CAT CGT TT & Manz et al. (1992) \\
CF319a & Bacteroidetes & TGG TCC GTG TCT CAG TAC & Manz et al. (1996) \\
ROS538 & Roseobacter clade of Alphaproteobacteria & CAA CGC TAA CCC CCT CC & Eilers et al. (2001) \\
ALT 1413 & Alteromonas clade of Gammaproteobacteria & TTT GCA TCC CAC TCC CAT & Eilers et al. (2000) \\
\hline
\end{tabular}




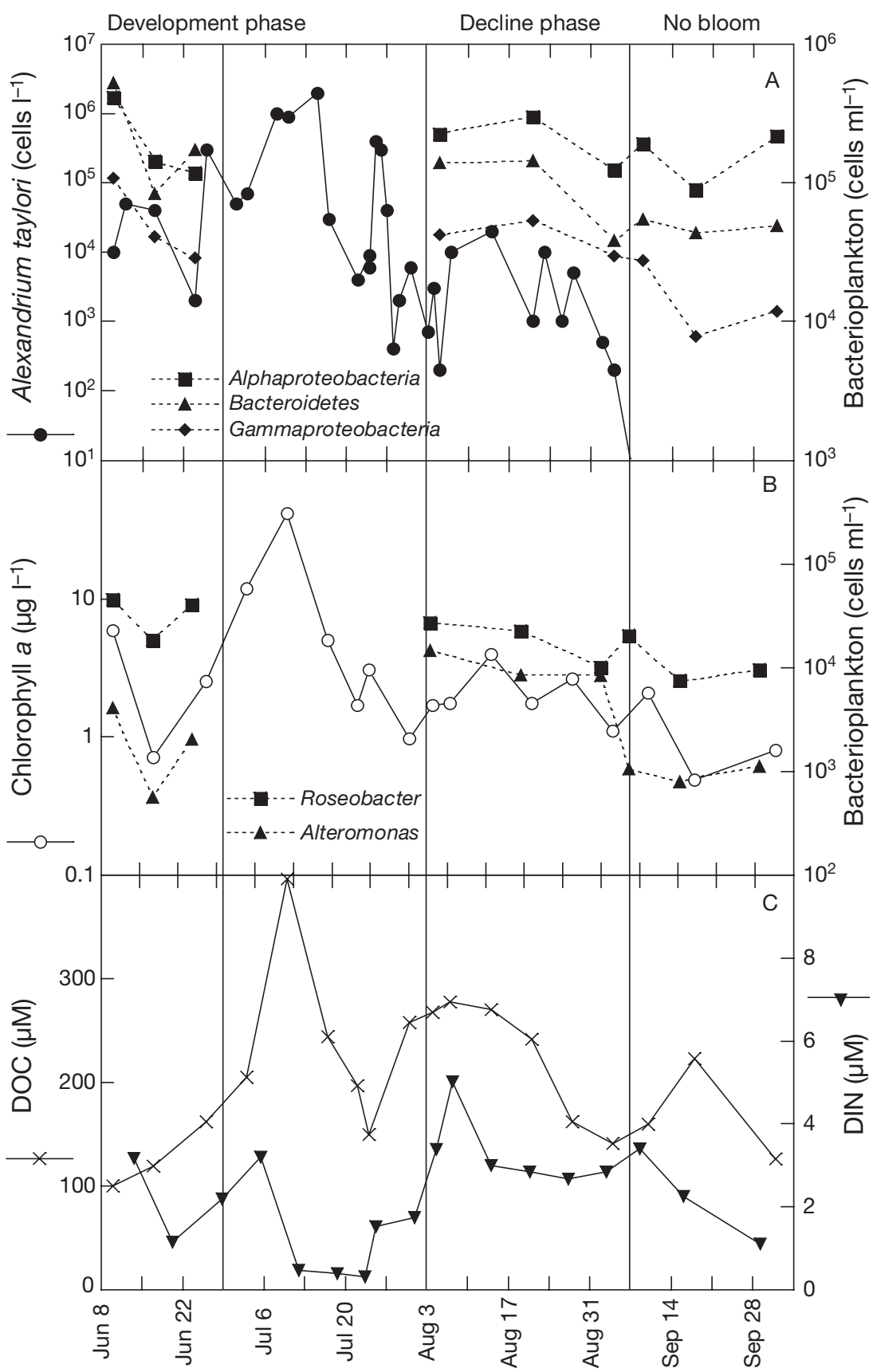

Fig. 2. (A) Temporal fluctuations of Alexandrium taylori cell density (cells $\mathbf{l}^{-1}$ ) in La Fosca beach surface waters in 2003 and co-occurring bacterioplankton groups: Alphaproteobacteria (Probe ALF968), Bacteroidetes (Probe CF319a) and Gammaproteobacteria (Probe GAM42a) enumerated by CARD-FISH. (B) Chlorophyll a concentration ( $\mu \mathrm{g} \mathrm{l}^{-1}$ ) and co-occurring abundances of Roseobacter (Probe ROS538) and Alteromonas (Probe ALT1413). (C) Dissolved organic carbon (DOC) and dissolved inorganic nitrogen (DIN) during the study period

bloom period, and showed a trend similar to that of the other bacterial groups.

Within the Alphaproteobacteria, members of the Roseobacter group showed a temporal trend similar to that of the general group, with maximum cell densities of $4 \times 10^{4}$ cells $\mathrm{ml}^{-1}$, declining down to $9 \times 10^{3}$ cells $\mathrm{ml}^{-1}$ in the non-bloom period. Within the Gammaproteobacteria, the Alteromonas cells (i.e. cells scoring positive with Probe ALT1413) were not very abundant during any period, reaching maximum cell densities of $1 \times 10^{4}$ cells $\mathrm{ml}^{-1}$ during the decline phase.

Bacteroidetes together with the Alphaproteobacteria always amounted to $>50 \%$ of DAPI counts (Fig. 3A). The 2 groups showed inverse trends: Alphaproteobacteria percent contribution increased from $31 \%$ of the total DAPIstainable cells in the developing phase to $36 \%$ in the decline phase and to $40 \%$ in the non-bloom period, whereas the Bacteroidetes varied, respectively, from 34 to 20 and to $13 \%$. Gammaproteobacteria never contributed $>8 \%$ of the bacterioplankton assemblage and decreased in the non-bloom period (4\%). The unidentified fraction of the cells (not accounted for by the 3 probes) was largest ( $44 \%$ of the total DAPIstainable cells) during the non-bloom period. Roseobacter were $19 \%$ of the Alphaproteobacteria group during the development phase, $24 \%$ during the decline phase and $\leq 8 \%$ during the non-bloom period (Fig. 3B). Alteromonas bacteria were, on average, $1 \%$ of the Gammaproteobacteria during both the development phase and the non-bloom period, whereas they reached up to $16 \%$ during the decline phase (details not shown).

\section{Spatial variation: the Alexandrium minutum bloom in Arenys Harbour}

High abundances of Alexandrium minutum (from $4 \times 10^{5}$ to $1 \times 10^{7}$ cells $\mathrm{l}^{-1}$ ) were found in the entire harbour, with maximum values at Stn 1 (Fig. 4). The values decreased towards the harbour entrance. Distribution patterns of chl a concurred with those of $A$. minutum cell abundance, with values varying between 1.9 and $6 \mu \mathrm{g} \mathrm{chl} \mathrm{a}^{-1}$. Average concentrations of phosphate $\left(\mathrm{P}-\mathrm{PO}_{4}\right)$ and ammonia $\left(\mathrm{N}-\mathrm{NH}_{3}\right)$ were 0.40 and $0.62 \mu \mathrm{M}$, respectively. $\mathrm{N}-\mathrm{NO}_{3}$ concentrations were $<2 \mu \mathrm{M}$ (details not shown). 

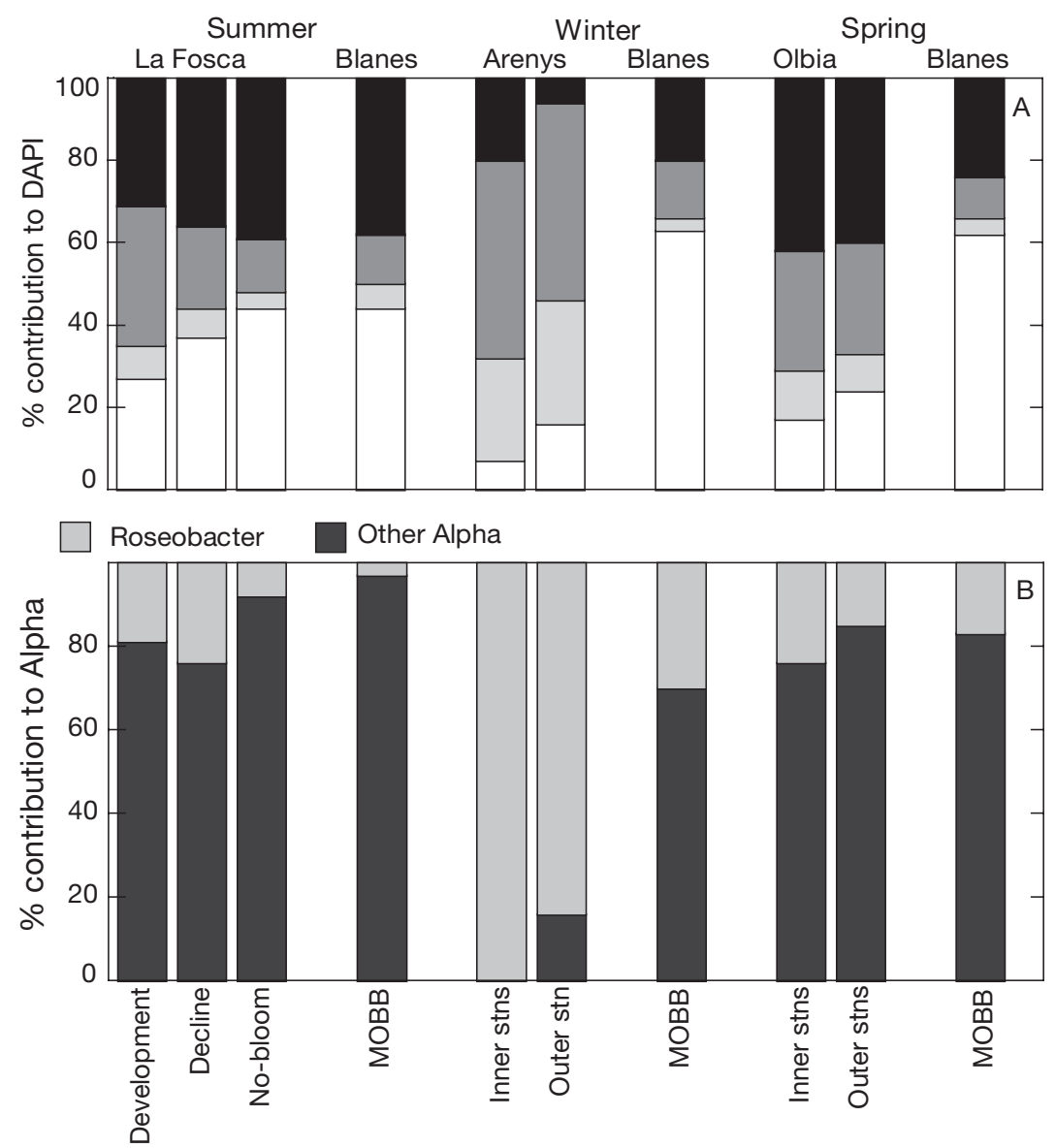

Fig. 3. (A) Percentage contribution to DAPI of Alphaproteobacteria (Probe ALFA968), Bacteroidetes (Probe CF319a) and Gammaproteobacteria (Probe GAM42a) detected by CARD-FISH in La Fosca beach surface waters in 2003 and, for the spatial studies, in Arenys Harbour in 2002 and Olbia Bay in 2003. Unidentified: cells not accounted for by the 3 probes. (B) Contribution of Roseobacter (Probe ROS538) to total Alphaproteobacteria (Alpha). Bloom stages are indicated in La Fosca sampling. Inner stations for Olbia Bay correspond to Stns 1 to 5, and outer stations are Stns 6 and 7. Inner stations for Arenys Harbour correspond to Stns 1 to 5, and the outer station is Stn 6. For comparison, percentages of the groups in samples from the Microbial Observatory of Blanes Bay (MOBB) during the different seasons of 2003 are plotted

We found similar detectability of bacteria with Probe EUB338 (81 to $91 \%$ of the total DAPI-stainable cells) and low proportions of negative control probe positive cells as in the previous area. High densities of bacterioplankton were detected for the Bacteroidetes ( $>10^{5}$ cells ml ${ }^{-1}$ at each station; Fig. 4A). Maxima of the 3 main groups were similar and were observed at Stn 4 $\left(3.3 \times 10^{5}\right.$ cells $\mathrm{ml}^{-1}$ for Alphaproteobacteria, $4 \times$ $10^{5}$ cells ml ${ }^{-1}$ for Bacteroidetes and $3.7 \times 10^{5}$ cells ml $^{-1}$ for Gammaproteobacteria).

The maximum densities of Roseobacter detected in Arenys Harbour $\left(2.5 \times 10^{5}\right.$ cells $\left.\mathrm{ml}^{-1}\right)$ were similar to those observed in Olbia Bay $\left(2.2 \times 10^{5}\right.$ cells ml ${ }^{-1}$; Fig. 5B) and exceeded the values measured at La Fosca beach, where the maximum was observed at the beginning of the development phase $\left(4 \times 10^{4}\right.$ cells $\mathrm{ml}^{-1}$; Fig. $\left.2 \mathrm{~B}\right)$.

The bacterioplankton assemblage in Arenys Harbour appeared quite constant, showing only a relatively lower presence of Alphaproteobacteria at the harbour entrance (Fig. 3A). Correspondingly, the percent contribution of Gammaproteobacteria increased (from $25 \%$ of the total DAPI-stainable cells in the inner part to $30 \%$ at the outer station). Roseobacter was the main group within the Alphaproteobacteria (from 84 to $100 \%$ of the Alphaproteobacteria cells), in contrast to the other coastal stations (Fig. 3B). Alteromonas never contributed $>16 \%$ of the Gammaproteobacteria, showing higher percent contributions at Stns 4 and 5 (Fig. 4B).

\section{Spatial variation: the Alexandrium spp. bloom in Olbia Bay}

This event was characterised by a relatively sparse dinoflagellate bloom $\left(2 \times 10^{4}\right.$ cells $\left.\mathrm{l}^{-1}\right)$. The maximum density of Alexandrium spp. was detected in the inner area $\left(4.4 \times 10^{3}\right.$ cells $\mathrm{l}^{-1}$ at Stn 1; Fig. 5A) and was 1 order of magnitude lower than the values achieved just a week before $\left(22 \times 10^{3}\right.$ cells $\mathrm{l}^{-1}$ at the same station, 3 May). Moreover, the Alexandrium spp. densities gradually decreased towards the bay entrance. The bloom was formed by 3 species: A. catenella, A. minutum and $A$. tamarense. Together they comprised up to $36 \%$ (at Stn 6) of the total dinoflagellate density (maximum of $17.4 \times 10^{3}$ cells $\mathrm{l}^{-1}$ at Stn 1). Distribution patterns of chl a (maximum of $25 \mu \mathrm{g} \mathrm{chl}$ a $\mathrm{l}^{-1}$ at Stn 1) showed a drastic decrease towards the bay entrance $\left(0.12 \mu \mathrm{g} \mathrm{l}^{-1}\right.$ at $\left.\mathrm{Stn} 7\right)$. Concentrations of phosphate $\left(\mathrm{P}^{\left.-\mathrm{PO}_{4}\right)}\right.$ were not $>0.04 \mu \mathrm{M}$ (Stn 1) and ammonia $\left(\mathrm{N}-\mathrm{NH}_{4}\right)$ ranged from 0.13 to $4.60 \mu \mathrm{M}$, respectively, at Stns 4 and 1 . The $\mathrm{N}-\mathrm{NO}_{3}$ maximum was $1.08 \mu \mathrm{M}$ at Stn 1 (details not shown).

Detection of bacteria with Probe EUB338 was more varied than at the other sites (63 to $90 \%$ of the total DAPI-stainable cells). Maximum densities of Alphaproteobacteria in Olbia Bay were up to ca. $10^{6}$ cells $\mathrm{ml}^{-1}$ (Stn 2; Fig. 5A) and exceeded those observed in 


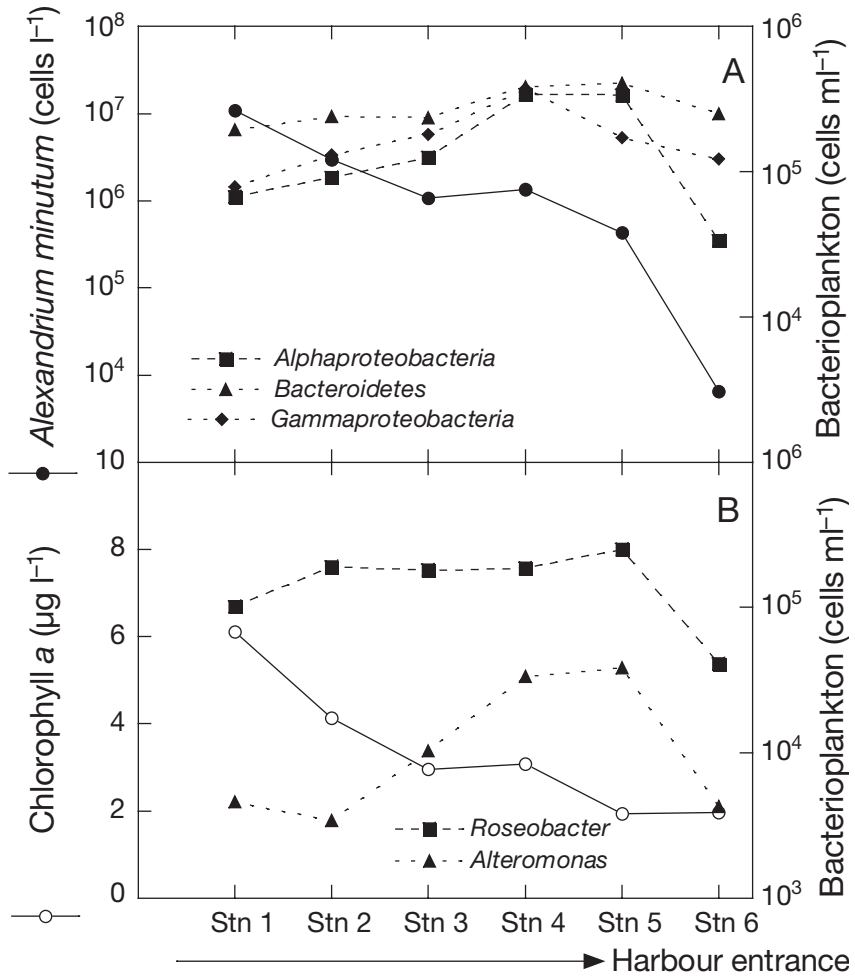

Fig. 4. (A) Alexandrium minutum cell density (cells $\mathrm{l}^{-1}$ ) and co-occurring abundances of Alphaproteobacteria (Probe ALF968), Bacteroidetes (Probe CF319a) and Gammaproteobacteria (Probe GAM42a) detected by CARD-FISH in the Arenys Harbour during the bloom period of 2002. (B) Chlorophyll a concentration ( $\mu \mathrm{g}^{-1}$ ) and co-occuring abundances of Roseobacter (Probe ROS538) and Alteromonas (Probe ALT1413). Note the different $y$-axis scales

Arenys Harbour and at La Fosca beach. The Bacteroidetes were also abundant in Olbia Bay (maximum of $6 \times 10^{5}$ cells ml ${ }^{-1}$ at Stn 2), whereas Gammaproteobacteria counts at this location were similar to those in other sampled areas, with a maximum of $3 \times 10^{5}$ cells $\mathrm{ml}^{-1}$ at $\mathrm{Stn} 2$. The values were similar at all inner stations (Stns 1 to 5), but lower towards the outer stations (Stns 6 and 7). Bacterioplankton assemblages appeared quite stable on a rather large spatial scale $(10 \mathrm{~km})$, showing little change in percentage composition from the inner to the outer stations (Fig. 3A), in spite of the large change in bacterial abundance. However, Roseobacter contributed from 14 (outer stations) to $43 \%$ (inner stations) to the Alphaproteobacteria group (Fig. 3B), whereas Alteromonas were $<9 \%$ of the Gammaproteobacteria group, being more important in the inner part of the bay.

For comparison, we followed a 1 yr annual cycle at the MOBB, a relatively open station not known to be affected by dinoflagellate blooms. There, detection of bacteria by Probe EUB338 ranged from 63 to $85 \%$ of the total DAPI-stainable cells. The maximum contri-

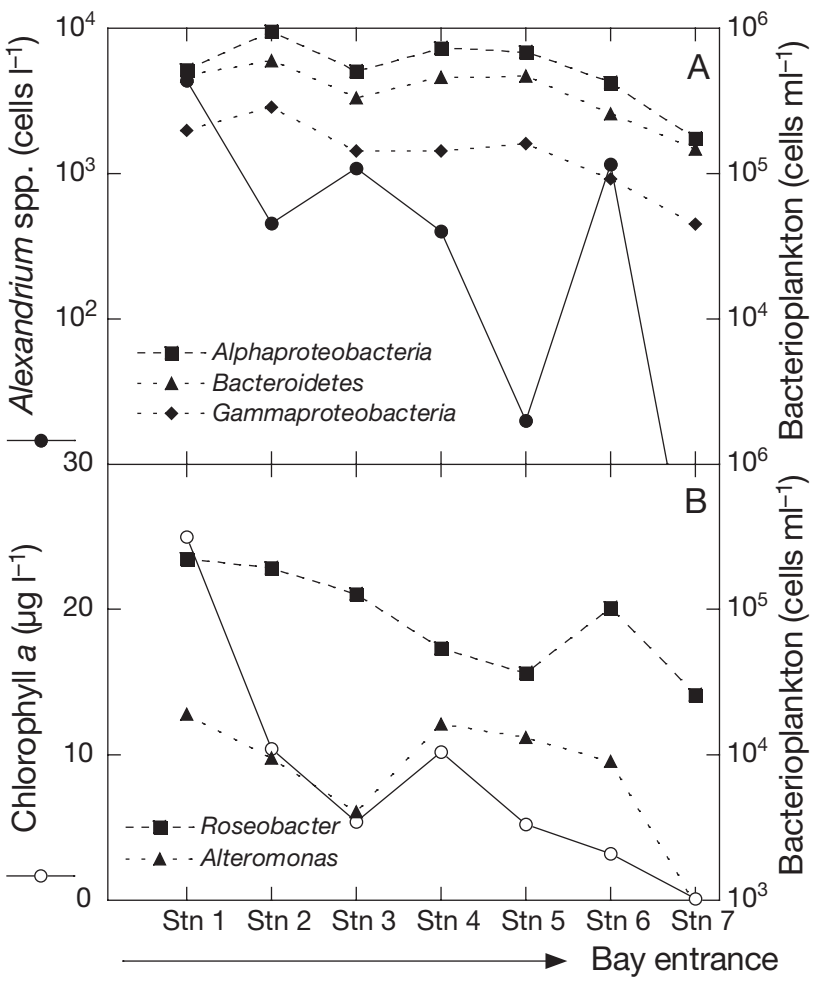

Fig. 5. (A) Alexandrium spp. cell density (cells $\mathrm{l}^{-1}$ ) and cooccurring abundance of Alphaproteobacteria (Probe ALF968), Bacteroidetes (Probe CF319a) and Gammaproteobacteria (Probe GAM42a) detected by CARD-FISH in Olbia Bay during the dinoflagellate bloom period of 2002. (B) Chlorophyll a concentration ( $\mu \mathrm{g} \mathrm{l}^{-1}$ ) and co-occuring abundances of Roseobacter (Probe ROS538) and Alteromonas (Probe ALT1413)

bution of the 3 main groups of bacterioplankton during summer (June, August and September) corresponded to Alphaproteobacteria (38\% of the total DAPI-stainable cells), followed by Bacteroidetes $(12 \%)$. During winter (December, January and February), Alphaproteobacteria contributed, on average, $20 \%$ of the total DAPI-stainable cells, followed by the Bacteroidetes $(14 \%)$. During spring, the percent contribution of Alphaproteobacteria was higher $(24 \%$ of the total DAPI-stainable cells), while Bacteroidetes $(12 \%)$ remained roughly at the same level (Fig. 3A). Roseobacter contributed from 3 to $30 \%$ to the Alphaproteobacteria from summer to winter, and Alteromonas were from 0 to $50 \%$ of the Gammaproteobacteria (data not shown). Bacterial assemblage structure, in terms of contribution of the main groups to total DAPI abundance in samples from this coastal station (MOBB), was rather similar to that found at La Fosca beach during non-bloom conditions (Fig. 3A), but strongly differed from that attained in the enclosed ecosystems of Arenys de Mar Harbour and Olbia Bay. 


\section{Bacteria growing in Alexandrium cultures}

The bacterioplankton assemblages associated with Alexandrium spp. cultures were very different from the natural bacterial assemblages during blooms of the same species (Fig. 6). In the case of A. taylori (a culture isolated from La Fosca beach), the dominating bacterioplankton group during the exponential phase of the culture was Gammaproteobacteria, while this group was less abundant during the maintenance phase (Fig. 6). When the culture was 1 yr old, Gammaproteobacteria and Alphaproteobacteria co-dominated the bacterioplankton assemblage (both representing $60 \%$ of the total DAPI-stainable cells). Few Bacteroidetes were detected during the exponential phase, whereas

Alphaproteobacteria $\square$ Bacteroidetes $\square$ Gammaproteobacteria $\square$ Unidentified
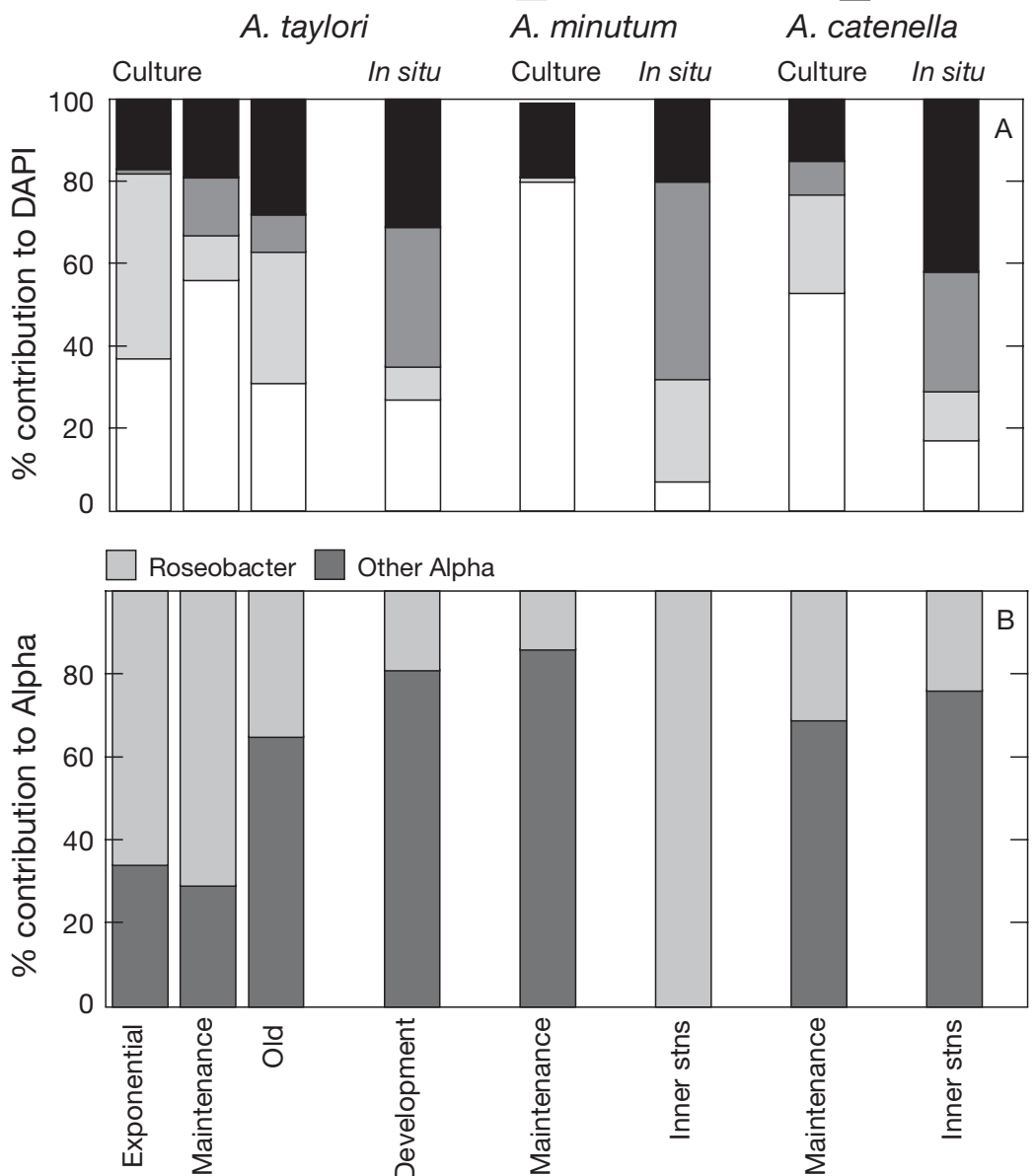

Fig. 6. (A) Percentage contribution to DAPI of Alphaproteobacteria (ALFA968), Bacteroidetes (CF319a) and Gammaproteobacteria (GAM42a) detected by CARD-FISH in Alexandrium taylori, A. minutum and A. catenella cultures. Unidentified: cells not accounted for by the 3 probes. (B) Percentage contribution of Roseobacter (ROS538) to total Alphaproteobacteria (Alpha). For comparison, the percentage of the groups in the development-stage samples from La Fosca beach (Development) and from the inner stations for Arenys Harbour and Olbia Bay are plotted. Exponential, maintenance and old refer to different phases of the culture during the maintenance phase they comprised $14 \%$ of total abundance. Roseobacter comprised from 35 to $71 \%$ of the Alphaproteobacteria group. In the A. minuculture (isolated from Arenys Harbour), Alphaprore a large percent of the EUB-positive bacteria contrast to the in situ samples, Roseobacter was not the DAPI-stainable cells). Similar percentages of Roseobacter were found in the culture and in situ samples.

Alteromonas were not $>2 \%$ of the Gammaproteobacteria in all the Alexandrium spp. cultures (details not shown).

\section{Correlation analysis}

Chlorophyll a was significantly positively correlated with bacterial EUBpositive bacteria cell concentration (Table 3), as well as with Bacteroidetes. Among the bacterioplankton groups, Roseobacter was significantly correlated to Alexandrium cell densities and temperature. Neither total nitrogen nor phosphorus concentrations were correlated with any of the bacterioplankton group abundance data.

\section{DISCUSSION}

Different coastal locations known to be affected by HAB were sampled to study the taxonomic composition of the dinoflagellate communities and the associated bacterioplankton assemblages during bloom and non-bloom conditions. The results obtained were used to discuss whether algal blooms actually alter the composition of the bacterioplankton community and to what extent these alterations are associated with the bloom-dominating algal species. Dinoflagellate cultures were also examined to evaluate whether the observed in situ associations also applied to clonal isolates of the bloomdominating algal species. We provide 
Table 3. Pearson correlation coefficients between chlorophyll a concentration ( $\mathrm{chl} a, \mu \mathrm{g} \mathrm{l} \mathrm{l}^{-1}$ ), $\mathrm{PO}_{4}$ and dissolved inorganic nitrogen concentration (DIN, $\mu \mathrm{M})$, Alexandrium sp. densities (Alex, cells $\mathrm{l}^{-1}$ ), dinoflagellate total cell densities (Dinos, cells $\mathrm{l}^{-1}$ ), bacterial DAPI counts (DAPI, cells ml ${ }^{-1}$ ), EUB cell concentrations (EUB, cells ml ${ }^{-1}$ ), Roseobacter cell concentrations (Roseo, cells ml ${ }^{-1}$ ), Alphaproteobacteria cell concentrations $\left(\alpha\right.$, cells $\left.\mathrm{ml}^{-1}\right)$, Bacteroidetes cell concentrations (Bac, cells $\left.\mathrm{ml}^{-1}\right)$, Gammaproteobacteria cell concentrations $\left(\gamma\right.$, cells $\left.\mathrm{ml}^{-1}\right)$ and Alteromonas-like cell concentrations (Alt, cells $\mathrm{ml}^{-1}$ ). Biological variables were log-transformed before analysis $(\mathrm{N}=27)$. Highly significant $\left({ }^{* *} \mathrm{p}<0.0005\right)$ and less significant $\left({ }^{*} \mathrm{p}<0.005\right.$ to 0.05$)$ correlations are shown

\begin{tabular}{|c|c|c|c|c|c|c|c|c|c|c|c|c|}
\hline $\log \operatorname{chl} a$ & 1 & & & & & & & & & & & \\
\hline $\mathrm{PO}_{4}$ & 0.590 & 1 & & & & & & & & & & \\
\hline Log Alex & 0.235 & 0.488 & 0.127 & 1 & & & & & & & & \\
\hline Log Dinos & 0.268 & 0.585 & 0.303 & $0.904^{* *}$ & 1 & & & & & & & \\
\hline Log DAPI & 0.590 & -0.132 & -0.495 & -0.072 & -0.213 & 1 & & & & & & \\
\hline $\log \alpha$ & 0.383 & 0.005 & -0.555 & -0.320 & -0.385 & $0.853^{* *}$ & 0.531 & 0.075 & 1 & & & \\
\hline Log Bac & $0.657^{*}$ & 0.144 & -0.085 & 0.451 & 0.310 & $0.666^{* *}$ & 0.865 & $0.795^{* *}$ & 0.379 & 1 & & \\
\hline $\log \gamma$ & 0.600 & 0.254 & -0.131 & 0.547 & 0.453 & $0.635^{* *}$ & $0.886^{* *}$ & $0.853^{* *}$ & 0.307 & $0.881^{* *}$ & * 1 & \\
\hline Log Alt & -0.550 & -0.515 & 0.019 & -0.087 & -0.093 & 0.733 & 0.546 & 0.525 & 0.749 & 0.767 & 0.663 & 1 \\
\hline
\end{tabular}

quantitative data on the abundance of the main marine bacterioplankton groups (Alphaproteobacteria, Bacteroidetes and Gammaproteobacteria) and additional information on some specific subgroups (Roseobacter and Alteromonas). These were selected on the basis of previously published information that suggested that these groups tended to be encountered in association with growing dinoflagellates (Table 1).

We have found no evident specificity of association between the bacterioplankton assemblage and the dinoflagellates. Alphaproteobacteria was the most abundant group in the Olbia study, with Bacteroidetes being the second. Bacteroidetes were abundant in the development phase of the La Fosca beach bloom, but decreased during the decline phase, when Alphaproteobacteria became the most important group. Gammaproteobacteria contributed in low proportions without significant changes throughout the different bloom phases and localities. Alteromonas-like organisms (Probe ALT1413) were never an important fraction of the assemblage, while Roseobacter were the main specific group within the Alphaproteobacteria in the A. minutum bloom (Arenys Harbour). This latter case will be discussed below, since the bacterial assemblage structure could represent a characteristic situation of a dense dinoflagellate bloom.

The lack of specificity in our study (e.g. in the cases of Alexandrium minutum and A. catenella) seems contradictory to some previous work. This could be due to the methodologies used or due to the differences between studies done on dinoflagellate cultures and those done on in situ communities. The studies published to date are dominated by the use of plate isolation and, in a few cases, PCR-based fingerprinting techniques, such as denaturing gradient gel elec- trophoresis (DGGE) or terminal restriction fragment length polymorphism (T-RFLP). Furthermore, most studies have described the bacterial assemblages associated with dinoflagellate cultures and extrapolated from them. Our approach was to use PCR-independent CARD-FISH to analyze the group-level diversity of the bacterial assemblages. The comparison between bacterial assemblage structure assessed by a PCR technique, i.e. DGGE, and FISH is not straightforward. DGGE and T-RFLP are fingerprinting techniques with a higher resolution in the description of the assemblage structure, but that might be subject to biases introduced by DNA extraction and the polymerase chain reaction, such as chimera and heteroduplex formation, template annealing and preferential amplification of some DNA templates (Wintzingerode et al. 1997). These biases can lead to uncertainties in the quantitative interpretation of the results. The FISH technique has a lower resolution level, since the number of probes used for each sample is limited and one can often miss the diversity within each broad phylogenetic group. Counting under the microscope also makes it a time-consuming technique, and, thus, the number of samples that can be handled is usually lower. Furthermore, the method itself can be subject to technical problems, such as non-specific binding of the probes (Pernthaler et al. 2002) or lack of coverage of some of the probes (e.g. Manz et al. 1996).

The generalisation that only a few groups dominate the bacterioplankton assemblages during HAB events (Table 1) also suffers from a large proportion of the available literature pertaining to dinoflagellate cultures; natural blooms have only seldom been studied with PCR and culture-independent techniques (e.g. Tobe et al. 2001). Studies in unialgal cultures growing 
in nutrient-enriched medium under laboratory conditions are quite different from the in situ assemblage subjected to variable natural conditions. In our study, Alphaproteobacteria (Fig. 6) comprised the only group showing similar percentages in both culture and natural populations.

Furthermore, while specific groups of Gammaproteobacteria, such as Alteromonadaceae, seem to be dominant in literature reports (Table 1), we could not retrieve them from any site in significant proportions. Other contradictory data appear in the comparison of natural and culture samples, e.g. the relevance of the Bacteroidetes during the maintenance and 1 yr old culture, while during the bloom of the same dinoflagellate, $A$. taylori, this group was abundant only in the exponential phase. More inconsistent is the contribution of Roseobacter in the A. minutum cultures, since in the field studies this bacterial group contributed a large fraction to the Alphaproteobacteria, while in the cultures it did not represent $>14 \%$. Caution should be taken with the extrapolation of observations obtained in laboratory dinoflagellate cultures to the in situ conditions.

It is important to note that, according to Table 1, the main bacterioplankton groups appearing with harmful algal species should be Alphaproteobacteria, particularly Roseobacter, and Gammaproteobacteria, with few exceptions. These dominant groups are also those dominating in other phytoplankton blooms, such as those of diatoms and non-toxic dinoflagellates (Grossart et al. 2005).

The dominance of Roseobacter within the Alphaproteobacteria in the dense Alexandrium minutum bloom of Arenys Harbour might be considered a notable situation. Even though Alphaproteobacteria were only $20 \%$ of the total DAPI-stainable cells, $100 \%$ of the Alphaproteobacteria hybridised with the Roseobacter probe. Such high values were not observed at any other location sampled. The relationship found between Alexandrium cell abundance and Roseobacter was highly significant (Table 3). Members of the Roseobacter clade are known to be present and dominant in coastal bacterial assemblages, are ubiquitous across seasonal and spatial gradients, and have been found to be prevalent in cultures of Alexandrium (Adachi et al. 2003, Jasti et al. 2005).

Since our results indicate low specificity in the association between HABs and bacteria, then, what determines the structure of the bacterial assemblages co-occurring with the dinoflagellates? Variability among sites in the composition of the bacterioplankton has to be explained just by referring to the common seasonal changes in the environment (Pinhassi \& Hagström 2000), in the oceanographic conditions, or the physiological status of the cells in the bloom. Roseobacter, for example, were relevant only in the Arenys Harbour situation, which was sampled in winter. And at our reference station at Blanes Bay, Roseobacter has been seen to be a typical contributor to bacterial assemblage structure mainly in winter (Fig. 6).

Temporal and spatial studies revealed changes in the abundances of the main bacterial groups, which covaried in relation to the phytoplankton proxy chl $a$, but with no significant differences in the relative contributions of the main bacterial groups to the total assemblage (Table 3). We previously showed that the Alexandrium taylori bloom greatly affected the in situ dynamics of the heterotrophic bacterial abundance (Gasol et al. 2005), following the daily migrations of the dinoflagellate. We show here that these effects do not seem to translate into predictable changes in assemblage phylogenetic structure, at least at this temporal scale.

As a concluding remark, we hypothesise that the structure of the bacterial community does not only depend on the bloom species (toxic or non-toxic) that produces a bloom, but rather to the seasonal differences among blooms, having been sampled in winter (Arenys), versus spring (Olbia Bay) and summer (La Fosca). Also, an unexplored issue is the nature of the place where the bloom takes place, e.g. the type of confined areas (ports, bays, semi-closed beaches), a variable that was not explored in this study because we only sampled 1 situation of each type. Relatively similar bacterioplankton assemblage structures were found at La Fosca beach and at the coastal reference station (MOBB). Arenys Harbour and Olbia Bay were more confined sites in terms of water renewal, where a particular assemblage different from more open stations developed as showed in this study. The prevailing oceanographic conditions favour resuspension of particles, which may subsequently alter the nutrient status (organic and inorganic) and other aspects in the harbour. This would generate more microhabitats with a modified natural hydrodynamic regime (higher water stability and water residence time). Both factors are known to be favourable for the development of toxic dinoflagellate blooms in the Mediterranean Sea (Maso \& Garcés 2006), and, if we are correct, would also contribute to determining the structure of the bacterioplankton assemblage.

Acknowledgements. The authors thank R. Ventosa for the nutrient analyses, and L. Balart from the Servei CientíficoTècnic of the University of Barcelona, for analyses of DOC. The comments by K. van Lenning helped to improve an earlier version of the manuscript. This study was financed by the EU funded Research Project SEED (Life cycle transformations among HAB species, and the environmental and physiological factors that regulate them, GOCE-CT-2005-003875), Spanish project MODIVUS (CTM2005-04795/MAR) and by the contract between ACA and CSIC. E.G.'s work was supported by a Ramon y Cajal contract from the Spanish Ministry of Science and Education. 


\section{LITERATURE CITED}

Adachi M, Kanno T, Matsubara T, Nishijima T, Itakura S, Yamaguchi M (1999) Promotion of cyst formation in the toxic dinoflagellate Alexandrium (Dinophyceae) by natural bacterial assemblages from Hiroshima Bay, Japan. Mar Ecol Prog Ser 191:175-185

Adachi M, Matsuraba T, Okamoto R, Nishijima T, Itakura S, Yamaguchi M (2001) Inhibition of cyst formation in the toxic dinoflagellate Alexandrium (Dinophyceae) by bacteria from Hiroshima Bay, Japan. Aquat Microb Ecol 26: 223-233

Adachi M, Kanno T, Okamoto R (2003) Population structure of Alexandrium (Dinophyceae) cyst formation-promoting bacteria in Hiroshima Bay, Japan. Appl Environ Microbiol 69:6560-6568

Alavi M, Miller T, Erlandson K, Schneider R, Belas R (2001) Bacterial community associated with Pfiesteria-like dinoflagellate cultures. Environ Microb 3:380-396

Alonso-Sáez L, Balagué V, Sà EL, Sánchez O and 6 others (2007) Seasonal bacteria diversity in Mediterranean coastal waters: assessment through clone libraries fingerprinting and fluorescent in situ hybridization FEMS Microbiol Ecol (in press)

Alverca E, Biegala IC, Kennaway GM, Lewis J, Franca S (2002) In situ identification and localization of bacteria associated with Gyrodinium instriatum (Gymnodiniales, Dinophyceae) by electron and confocal microscopy. Eur J Phycol 37:523-530

Amann RI, Krumholz L, Stahl DA (1990) Fluorescent oligonucleotide probing of whole cells for determinative, phylogenetic, and environmental studies in microbiology. J Bacteriol 172:762-770

Amaro AM, Fuentes MS, Ogalde SR, Venegas JA, Suárez-Isla BA (2005) Identification and characterization of potentially algal-lytic marine bacteria strongly associated with the toxic dinoflagellate Alexandrium catenella. J Eukaryot Microbiol 52:191-200

Babinchak JA, McGovern ER, Doucette GJ (1998) Isolation and characterization of the bacterial flora associated with PSP-related dinoflagellate species. In: Reguera B, Blanco J, Fernandez ML, Wyatt T (eds) Harmful algae. Xunta de Galicia \& IOC-UNESCO, Santiago de Compostela, p 410-413

Balech E (1995) The genus Alexandrium Halim (Dinoflagellata). Sherkin Island Marine Station, Sherkin Island

Biegala IC, Kennaway G, Alverca E, Lennon JF, Vaulot D, Simon N (2002) Identification of bacteria associated with dinoflagellates (Dinophyceae): Alexandrium spp. using tyramide signal amplification-fluorescent in situ hybridization and confocal microscopy. J Phycol 38:404-411

Böckelmann U, Manz W, Neu TR, Szewzyk U (2000) Characterization of the microbial community of lotic organic aggregates (river snow) in the Elbe River of Germany by cultivation and molecular methods. FEMS Microbiol Ecol 33:157-170

Brinkmeyer R, Rappé M, Gallacher S, Medlin L (2000) Development of clade- (Roseobacter and Alteromonas) and taxon-specific oligonucleotide probes to study interactions between toxic dinoflagellates and their associated bacteria. Eur J Phycol 35:315-329

Buck JD, Pierce RH (1989) Bacteriological aspects of Florida red tides: a revisit and newer observations. Estuar Coast Shelf Sci 29:317-326

Castle D, Kirchman DL (2004) Composition of estuarine bacterial communities assessed by denaturing gradient gel electrophoresis and fluorescence in situ hybridization.
Limnol Oceanogr Methods 2:303-314

Cole JJ (1982) Interactions between bacteria and algae in aquatic ecosystems. Annu Rev Ecol Syst 13:291-314

Córdova JL, Cárdenas L, Yudelevich A (2002) Multiple bacterial infection of Alexandrium catenella (Dinophyceae). J Plankton Res 24:1-8

Daims H, Brühl A, Amann R, Schleifer KH, Wagner M (1999) The domain-specific probe EUB338 is insufficient for the detection of all Bacteria: development and evaluation of a more comprehensive probe set. Syst Appl Microbiol 22:434-444

DeLong EF, Franks DG, Alldredge AL (1993) Phylogenetic diversity of aggregate-attached vs. free-living marine bacterial assemblages. Limnol Oceanogr 38:924-934

Doucette GJ (1995) Interactions between bacteria and harmful algae: a review. Nat Toxins 3:65-74

Doucette GJ, Trick CG (1995) Characterization of bacteria associated with different isolates of Alexandrium tamarense. In: Lassus P, Arzul G, Erard E, Gentien P, Marcaillou C (eds) Harmful marine algal blooms. Lavoisier, Paris, p 33-38

Doucette GJ, Kodama M, Franca S, Gallacher S (1998) Bacterial interactions with harmful algal bloom species: bloom ecology, toxigenesis and cytology. In: Anderson DA, Cembella AD, Hallegraeff GM (eds) Physiological ecology of harmful algal blooms, Vol 41. Springer-Verlag, Heidelberg, p 29-48

Doucette GJ, McGovern ER, Babinchak JA (1999) Algicidal bacteria active against Gymnodinium breve (Dinophyceae). I. Bacterial isolation and characterization of killing activity. J Phycol 35:1447-1454

Duarte CM, Agustí S, Kennedy H, Vaqué D (1999) The Mediterranean climate as a template for Mediterranean marine ecosystems. The example of the northeast Spanish littoral. Prog Oceanogr 44:245-270

Eilers H, Pernthaler J, Amann R (2000) Succession of pelagic marine bacteria during enrichment: a close look at cultivation-induced shifts. Appl Environ Microbiol 66:4634-4640

Eilers H, Pernthaler J, Peplies J, Gloeckner FO, Gerdts G, Amann R (2001) Isolation of novel pelagic bacteria from the German Bight and their seasonal contributions to surface picoplankton. Appl Environ Microbiol 67:5134-5142

Fandino L, Riemann L, Steward G, Long R, Azam F (2001) Variations in bacterial community structure during a dinoflagellate bloom analyzed by DGGE and 16S rDNA sequencing. Aquat Microb Ecol 23:119-130

Fandino L, Riemann L, Steward G, Azam F (2005) Population dynamics of Cytophaga-Flavobacteria during marine phytoplankton blooms analyzed by real-time quantitative PCR. Aquat Microb Ecol 40:251-257

Ferrier M, Martin JL, Rooney-Varga JN (2002) Stimulation of Alexandrium fundyense growth by bacterial assemblages from the Bay of Fundy. J Appl Microbiol 92:706-716

Franca S, Viegas S, Mascarenhas V, Pinto L, Doucette GJ (1995) Prokaryotes in association with a toxic Alexandrium lusitanicum in culture. In: Lassus $\mathrm{P}$, Arzul G, Erard E, Gentien P, Marcaillou C (eds) Harmful marine algal blooms. Lavoisier, Paris, p 45-51

Franca S, Pinto L, Alvito P, Sousa I, Vasconcelos V, Doucette GJ (1996) Studies on prokaryotes associated with PSPproducing dinoflagellates. In: Yasumoto $\mathrm{T}$, Oshima $\mathrm{Y}$, Fukuyo Y (eds) Harmful and toxic algal blooms. IOCUNESCO, Paris, p 347-350

Fritz L, Triemer RE (1985) A rapid simple technique utilizing calcofluor white M2R for the visualization of dinoflagellate thecal plates. J Phycol 21:662-664

Fukami K, Nishijima T, Murata H, Doi S, Hata Y (1991) Distribution of bacteria influential on the development and the 
decay of Gymnodinium nagasakiense red tide and their effects on algal growth. Nippon Suisan Gakkaishi 57: 2321-2326

Gallacher S, Flynn KL, Franco JM, Brueggemann EE, Hines HB (1997) Evidence for production of paralytic shellfish toxins by bacteria associated with Alexandrium spp. (Dinophyta) in culture. Appl Environ Microbiol 63:239-245

Garcés E, Delgado M, Maso M, Camp J (1998) Life history and in situ growth rates of Alexandrium taylori (Dinophyceae, Pyrrophyta). J Phycol 34:880-887

Garcés E, Masó M, Camp J (1999) A recurrent and localized dinoflagellate bloom in a Mediterranean beach. J Plankton Res 21:2373-2391

Garcés E, Masó M, Camp J (2002) Role of temporary cysts in the population dynamics of Alexandrium taylori (Dinophyceae). J Plankton Res 24:681-686

Garcés E, Vila M, Maso M, Sampedro N, Giacobbe MG, Penna A (2005) Taxon-specific analysis of growth and mortality rates of harmful dinoflagellates during bloom conditions. Mar Ecol Prog Ser 301:67-79

Gasol JM, Duarte CM (2000) Comparative analyses in aquatic microbial ecology: How far do they go? FEMS Microbiol Ecol 31:99-106

Gasol JM, Garcés E, Vila M (2005) Strong small-scale temporal bacterial changes associated with the migrations of bloom-forming dinoflagellates. Harmful Algae 4:771-781

Glöckner FO, Fuchs BM, Amann R (1999) Bacterioplankton composition of lakes and oceans: a first comparison based on fluorescence in situ hybridization. Appl Environ Microbiol 65:3721-3726

González JM, Moran MA (1997) Numerical dominance of a group of marine bacteria in the alpha-subclass of the class Proteobacteria in coastal seawater. Appl Environ Microbiol 63:4237-4242

Granéli E, Turner JT (eds) (2006) Ecology of harmful algae, Vol 189. Springer-Verlag, Berlin

Grasshoff K, Ehrrardt M, Kremling K (1983) Methods of sea water analysis. Verlag Chemie, Weinheim

Green D, Llewellyn L, Negri A (2004) Phylogenetic and functional diversity of the cultivable bacterial community associated with the paralytic shellfish poisoning dinoflagellate Gymnodinium catenatum. FEMS Microbiol Ecol 47: 345-357

Groben R, Doucette GJ, Kopp M, Kodama M, Amann R, Medlin LK (2000) 16S rRNA targeted probes for the identification of bacterial strains isolated from cultures of the toxic dinoflagellate Alexandrium tamarense. Microb Ecol 39:186-196

Grossart H, Levold F, Allgaier M, Simon M, Brinkhoff T (2005) Marine diatom species harbour distinct bacterial communities. Environ Microb 7:860-873

Guillard RRL (1975) Culture of phytoplankton for feeding marine invertebrates. In: Smith WL, Chanley MH (eds) Culture of marine invertebrate animals. Plenum Press, New York, p 29-60

Hold GL, Smith E, Birkbeck TH, Gallacher S (2001a) Comparison of paralytic shellfish toxin (PST) production by the dinoflagellates Alexandrium lusitanicum NEPCC 253 and Alexandrium tamarense NEPCC 407 in the presence and absence of bacteria. FEMS Microbiol Ecol 36: 223-234

Hold GL, Smith EA, Rappe MS, Maas EW and 6 others (2001b) Characterisation of bacterial communities associated with toxic and non-toxic dinoflagellates: Alexandrium spp. and Scrippsiella trochoidea. FEMS Microbiol Ecol 37:161-173

Ishida YI, Yoshinaga MC, Kim, Uchima A (1997) Possibility of bacterial control of harmful algal blooms. In: En MT, Martins MIZ, Sato JM, Tiedje LCN, Hagler J (eds) Progress in microbial ecology. S.B.M./ICO-ME, p 495-500

Jasti S, Sieracki ME, Poulton NJ, Giewat MW, Rooney-Varga JN (2005) Phylogenetic diversity and specificity of bacteria closely associated with Alexandrium spp. and other phytoplankton. Appl Environ Microbiol 71:3483-3494

Kodama M, Ogata T, Sakamoto S, Sato S, Honda T, Miwatani $T$ (1990) Production of paralytic shellfish toxins by a bacterium Moraxella sp. isolated from Protogonyaulax tamarensis. Toxicon 28:707-714

Kodama M, Doucette GJ, Green DH (2006) Relationships between bacteria and harmful algae. In: Granéli E, Turner JT (eds) Ecology of harmful algae, Vol 189. Springer-Verlag, Berlin, p 243-255

Kopp M, Doucette GJ, Kodama M, Gerdts G, Schütt C, Medlin L (1997) Phylogenetic analysis of selected toxic and non-toxic bacterial strains isolated from the toxic dinoflagellate Alexandrium tamarense. FEMS Microbiol Ecol 24:251-257

Lafay B, Ruimy R, Rausch de Traubenberg C, Breittmayer V, Gauthier MJ, Christen R (1995) Roseobacter algicola sp. nov., a new marine bacterium isolated from the phycosphere of the toxin-producing dinoflagellate Prorocentrum lima. Int J Syst Evol Microbiol 45:290-296

Lu YH, Chai TJ, Hwang DF (2000) Isolation of bacteria from toxic dinoflagellate Alexandrium minutum and their effects on algae toxicity. J Nat Toxins 9:409-417

Lugliè A, Giacobbe MG, Fiocca F, Sannio A, Sechi N (2003a) The geographical distribution of Alexandrium catenella is extending to Italy! First evidences from the Tyrrhenian Sea. In: Steidinger ALJ, Tomas CR, Vargo GA (eds) Harmful algae 2002. Proceedings of the 10th international conference on harmful algae. Florida Fish and Wildlife Conservation Commission and Intergovernmental Oceanographic Commission of UNESCO, St Petersburg, FL, p 329-331

Lugliè A, Giacobbe MG, Sannio A, Fiocca F, Sechi N (2003b) First record of the dinoflagellate Alexandrium catenella (Whedon \& Kofoid) Balech (Dinophyta), a potential producer of paralytic shellfish poisoning, in Italian waters (Sardinia, Tyrrhenian Sea). Bocconea 16:1045-1052

Lugliè A, Soru O, Vila M, Masó M, Satta C, Padedda B, Sechi N (2006) Dinamica giornaliera del fitoplancton nel Golfo di Olbia con particolare attenzione a specie del genera Alexandrium (Daily dynamics of phytoplankton in the Gulf of Olbia, paying particular attention to species of the Alexandrium genus-Dinophyceae). Biol Mar Medit 13(1):1020-1024

Manz W, Amann R, Ludwig W, Wagner M, Schleifer KH (1992) Phylogenetic oligonucleotide probes for the major subclasses of Proteobacteria: problems and solutions. Syst Appl Microbiol 15:593-600

Manz W, Amann R, Ludwig W, Vancanneyt M, Schleifer KH (1996) Application of a suite of 16S rRNA-specific oligonucleotide probes designed to investigate bacteria of the phylum Cytophaga-Flavobacter-Bacteroides in the natural environment. Microbiology 142:1097-1106

Maso M, Garcés E (2006) Harmful microalgae blooms (HAB): problematic and conditions that induce them. Mar Pollut Bull 53:620-630

Mayali X, Azam F (2004) Algicidal bacteria in the sea and their impact on algal blooms. J Eukaryot Microbiol 51: 139-144

Onji M, Sawabe T, Ezura Y (1995) Effect of marine bacteria isolated from Tanabe Bay on the growth of marine red tide dinoflagellate, Gymnodinium mikimotoi. Bull Fac Fish Hokkaido Univ 46:39-46 
Pernthaler A, Pernthaler J, Amann R (2002) Fluorescence in situ hybridization and catalyzed reporter deposition for the identification of marine bacteria. Appl Environ Microbiol 68:661-667

Pinhassi J, Hagström $\AA$ (2000) Seasonal succession in marine bacterioplankton. Aquat Microb Ecol 21:245-256

Pinhassi J, Sala MM, Havskum H, Peters F, Guadayol O, Malits A, Marrase CL (2004) Changes in bacterioplankton composition under different phytoplankton regimens. Appl Environ Microbiol 70:6753-6766

Prokic I, Brummer F, Brigge T, Gortz HD, Gerdts G, Schutt C, Elbrachter M, Muller WEG (1998) Bacteria of the genus Roseobacter associated with the toxic dinoflagellate Prorocentrum lima. Protist 149:347-357

Riemann L, Steward GF, Azam F (2000) Dynamics of bacterial community composition and activity during a mesocosm diatom bloom. Appl Environ Microbiol 66:578-587

Romalde JL, Toranzo AE, Barja JL (1990) Changes in bacterial populations during red tides caused by Mesodinium rubrum and Gymnodinium catenatum in north west coast of Spain. J Appl Bacteriol 68:123-132

Sakami T, Nakahara H, Chinain M, Ishida Y (1999) Effects of epiphytic bacteria on the growth of the toxic dinoflagellate Gambierdiscus toxicus (Dinophyceae). J Exp Mar Biol Ecol 233:231-246

Sala MM, Balagué V, Pedrós-Alió C, Massana R, Felipe J, Arin L, Illoul H, Estrada M (2005) Phylogenetic and functional diversity of bacterioplankton during Alexandrium spp. blooms. FEMS Microbiol Ecol 54:257-267

Sannio A, Luglie A, Sechi N (1997) Potentially toxic dinoflagellates in Sardinia. Plant Biosyst 131:73-78

Schweitzer B, Huber I, Amann R, Ludwig W, Simon M (2001) Alpha- and beta-proteobacteria control the consumption and release of amino acids on lake snow aggregates. Appl Environ Microbiol 67:632-645

Strickland JDH, Parsons TR (1972) A practical handbook of seawater analysis. Fisheries Research Board of Canada, Ottawa

Sugimura Y, Suzuki Y (1998) A high-temperature catalytic oxidation method for the determination of non-volatile dissolved organic carbon in seawater by direct injection of a liquid sample. Mar Chem 24:105-131

Suzuki MT, Rappe MS, Haimberger ZW, Winfield H, Adair N, Strobel J, Giovannoni SJ (1997) Bacterial diversity among

Editorial responsibility: Edna Granéli, Kalmar, Sweden small-subunit rRNA gene clones and cellular isolates from the same seawater sample. Appl Environ Microbiol 63: 983-989

Throndsen J (1995) Estimating cell numbers. In: Hallegraeff GM, Anderson DM, Cembella DA (eds) Manual on harmful marine microalgae. IOC manuals and guides, Vol 33. UNESCO, Paris, p 63-80

Tobe K, Ferguson C, Kelly M, Gallacher S, Medlin LK (2001) Seasonal occurrence at a Scottish PSP monitoring site of purportedly toxic bacteria originally isolated from the toxic dinoflagellate genus Alexandrium. Eur J Phycol 36: $243-256$

Tosteson TR, Ballantine DL, Tosteson CG, Hensley V, Bardales AT (1989) Associated bacterial flora, growth, and toxicity of cultured benthic dinoflagellates Ostreopsis lenticularis and Gambierdiscus toxicus. Appl Environ Microbiol 55:137-141

Vaqué D, Blough HA, Duarte CM (1997) Dynamics of ciliate abundance, biomass and community composition in an oligotrophic coastal environment (NW Mediterranean). Aquat Microb Ecol 12:71-83

Vásquez M, Gruttner C, Gallacher S, Moore ERB (2001) Detection and characterization of toxigenic bacteria associated with Alexandrium catenella and Aulacomya after contaminated with ASP. J Shellfish Res 20:1245-1249

Vila M, Camp J, Garcés E, Maso M, Delgado M (2001) High resolution spatio-temporal detection of potentially harmful dinoflagellates in confined waters of the NW Mediterranean. J Plankton Res 23:497-514

Vila M, Giacobbe MG, Maso M, Gangemi E and 5 others (2005) A comparative study on recurrent blooms of Alexandrium minutum in two Mediterranean coastal areas. Harmful Algae 4:673-695

Wichels A, Hummert C, Elbrächter M, Luckas B, Schütt C, Gerdts G (2004) Bacterial diversity in toxic Alexandrium tamarense blooms off the Orkney Isles and the Firth of Forth. Helgol Mar Res 58:93-103

Wintzingerode F, Göbel UB, Stackebrandt E (1997) Determination of microbial diversity in environmental samples: pitfalls of PCR-based rRNA analysis. FEMS Microbiol Rev 21:213-229

Yentsch CS, Menzel DW (1963) A method for the determination of phytoplankton chlorophyll and phaeophytin by fluorescence. Deep-Sea Res 10:221-231

Submitted: May 2, 2006; Accepted: October 16, 2006

Proofs received from author(s): January 12, 2007 